\title{
General Personal Jurisdiction After Goodyear Dunlop Tires Operations, S.A. v. Brown
}

\author{
Michael H. Hoffheimer*
}

\section{INTRODUCTION}

In the last week of its 2010-2011 term, the Supreme Court announced two decisions that held that the Due Process Clause ${ }^{1}$ prohibits state courts from exercising personal jurisdiction over foreign manufacturers in certain situations. In Goodyear Dunlop Tires Operations, S.A. v. Brown, the Court held that foreign manufacturers' sales of a limited quantity of goods in a state did not subject the manufacturers to personal jurisdiction in that state for deaths of state residents that occurred outside the state and were caused by products sold outside the state. ${ }^{2}$ The unanimous opinion categorically distinguished between general and specific personal jurisdiction, ${ }^{3}$ making

\footnotetext{
* Professor of Law and Mississippi Defense Lawyers Association Distinguished Lecturer, University of Mississippi School of Law. I am grateful to Patrick J. Borchers, Joseph W. Glannon, Kermit Roosevelt III, and Michael E. Solimine for helpful comments on drafts of this Article.

1. U.S. CONST. amend. XIV. Though states have sovereign judicial power unless prohibited by state law or due process limits, the Court commonly writes as if federal law permits or authorizes jurisdiction. E.g., Calder v. Jones, 465 U.S. 783, 788 (1984) ("The Due Process Clause . . permits personal jurisdiction over a defendant in any State with which the defendant has 'certain minimum contacts' ....” (quoting Int'l Shoe Co. v. Washington, 326 U.S. 310, 316 (1945))). Two Justices have recently asserted that plaintiffs bear the burden of proving that state jurisdiction conforms to constitutional limits. See J. McIntyre Mach., Ltd. v. Nicastro, 131 S. Ct. 2780, 2791 (2011) (Breyer, J., concurring).

2. 131 S. Ct. 2846, 2851 (2011).

3. See id. (agreeing with the North Carolina Court of Appeals that North Carolina courts lacked specific jurisdiction, but holding that North Carolina courts also lacked general jurisdiction). The Court had previously differentiated between specific and general jurisdiction, see infra notes 108-09 and accompanying text, by borrowing terminology proposed by two prominent academics. As Professors von Mehren and Trautman explain:

[A]ffiliations between the forum and the underlying controversy normally support only the power to adjudicate with respect to issues deriving from, or connected with, the very controversy that establishes jurisdiction to adjudicate. This we call specific jurisdiction. On the other hand, American practice for the most part is to exercise power to adjudicate any kind of controversy when jurisdiction is based on relationships, direct or indirect, between the forum and the person or persons whose legal rights are to be affected. This we call general jurisdiction.
} 
clear that limited sales do not satisfy the "substantial" activity or "continuous and systematic" contacts required for general jurisdiction. ${ }^{4}$

In J. McIntyre Machinery, Ltd. v. Nicastro, the Court held that a state court lacks personal jurisdiction over claims by a state resident against a foreign manufacturer that sells a defective product to a distributor in the state where it causes injury. ${ }^{5}$ Justice Ginsburg, author of the unanimous opinion in Goodyear Dunlop Tires, dissented in Nicastro, protesting that the holding departed from precedent and expressing concern with the new theory of jurisdiction offered by the plurality. ${ }^{6}$

These decisions - the Court's first major opinions to address constitutional limits on adjudicatory jurisdiction in two decadesreceived little attention. Released during the slow summer news cycle, they yielded the headlines to controversial First Amendment cases decided the same day. ${ }^{7} \quad$ Goodyear Dunlop Tires, supported by a unanimous Court, predictably ${ }^{8}$ conformed to prior decisions that evidence the Court's reluctance to permit general jurisdiction over corporations based upon claims unrelated to corporate activity in the forum state. The decision received less attention than Nicastro, which

Arthur T. von Mehren \& Donald T. Trautman, Jurisdiction to Adjudicate: A Suggested Analysis, 79 HaRV. L. REV. 1121, 1136 (1966).

The contemporary use of general jurisdiction by courts and scholars corresponds to von Mehren and Trautman's category of "unlimited general jurisdiction," which they distinguished from quasi in rem jurisdiction. Id. at 1136.

4. Goodyear Dunlop Tires, 131 S. Ct. at 2851, 2853 (quoting Int'l Shoe, 326 U.S. at 317-18).

5. 131 S. Ct. at 2785, 2791 (plurality opinion). The Court failed to produce an opinion agreeable to a majority of its members. Justice Kennedy, writing for four Justices, expressed strong reservations about the stream-of-commerce metaphor that had informed prior opinions. Id. at 2788 ("The stream of commerce, like other metaphors, has its deficiencies as well as its utility."). Justice Kennedy also adumbrated a theory of personal jurisdiction that requires a defendant to submit to the authority of a sovereign. Id. at 2787-90; see also infra note 228.

6. Nicastro, 131 S. Ct. at 2799 (Ginsburg, J., dissenting) (“[T]he plurality’s notion that consent is the animating concept [of personal jurisdiction] draws no support from controlling decisions of this Court.”).

7. See, e.g., Brown v. Entm't Merchs. Ass'n, 131 S. Ct. 2729, 2742 (2011) (holding that the First Amendment protects sales of violent video games to minors); Ariz. Free Enter. Club’s Freedom Club PAC v. Bennett, 131 S. Ct. 2806, 2828-29 (2011) (holding that the First Amendment prevents states from providing funds to political candidates to match private funds raised by their opponents).

8. Cf. Email from author to Ronald J. Rychlak, Assoc. Dean, Univ. of Miss. Sch. of Law (March 8, 2011, 2:53 PM) (on file with author) ("I would like to apply for a summer research grant to support research on the following project[]: (1) evaluation of Supreme Court opinion (to be handed down in Goodyear v. Brown probably rejecting unanimously the idea of general jurisdiction based on third party sales) ....”" (italics added)). 
provoked a spirited dissent ${ }^{9}$ and was greeted with much criticism and alarm. $^{10}$

This Article reviews the Court's latest word on due process limits on general personal jurisdiction. The Court crafted the Goodyear Dunlop Tires opinion to provide needed guidance for lower courts. Nevertheless, this Article contends that the opinion achieved consensus only because it can be read in radically different ways. On the one hand, the Court framed its decision narrowly to establish that foreign manufacturers are not subject to general jurisdiction based on sporadic sales of products in the forum through intermediaries. ${ }^{11}$ On the other hand, the Court embraced a more general doctrine that limits general jurisdiction over corporations to places where they are "at home"12 - their places of incorporation, principal places of business, ${ }^{13}$ and, perhaps, places where they engage in such substantial, continuous, and systematic activity that those places are comparable to principal places of business. ${ }^{14}$

The opinion avoided dissension by omitting any discussion of the theoretical bases of jurisdiction and by withholding any examples of "substantial" or "systematic and continuous" activity. The opinion's narrowly framed issues and comparative evaluation of corporate activity $^{15}$ can support a flexible approach that approves general jurisdiction in multiple states where a foreign corporation has strong

9. Nicastro, 131 S. Ct. at 2794-2804 (Ginsburg, J., dissenting).

10. Debra Cassens Weiss, Is International Shoe Getting the Boot? Ginsburg Dissent Protests Jurisdictional Bar to Tort Suit, ABA J. (June 27, 2011, 2:03 PM), http://www.abajournal.com/ news/article/is_international_shoe_getting_the_boot_ginsburg_dissent_protests_jurisdicti.

Janice L. Heinhold, counsel of record for the plaintiff in Nicastro, observed that the decision "turned back the clock about 60 years" and provided a "roadmap for corporations" seeking to avoid liability for defective products in U.S. courts. Telephone Interview with Janice L. Heinhold, Assoc., Rakoski \& Ross, P.C. (July 1, 2011) (notes on file with author).

11. Goodyear Dunlop Tires Operations, S.A. v. Brown, 131 S. Ct. 2846, 2856 (2011). As the Court noted, "[M]ere purchases [made in the forum State], even if occurring at regular intervals, are not enough to warrant a State's assertion of [general] jurisdiction over a nonresident corporation in a cause of action not related to those purchase transactions." Id. (alterations in original) (quoting Helicopteros Nacionales de Colom., S.A. v. Hall, 466 U.S. 408, 418 (1984)) (internal quotation marks omitted). The narrow reading is evident from the opinion, which refers to the requirement of "continuous and systematic general business contacts" but does not employ the word "home" or phrase "at home" or suggest that such contacts must establish corporate presence comparable to the principal place of business. Id. at 2856 (quoting Helicopteros, 466 U.S. at 416).

12. Id. at 2853-54 (citing Lea Brilmayer et al., A General Look at General Jurisdiction, 66 Tex. L. Rev. 721 (1998)).

13. Id.

14. Id. at 2851 (citing Int'l Shoe Co. v. Washington, 326 U.S. 310, 317 (1945)).

15. See generally id. at 2856-57 (discussing the contacts in Perkins and Helicopteros as compared to those in Goodyear Dunlop Tires). 
permanent connections. Yet its formal doctrines can equally support a restrictive approach that limits general jurisdiction to the place of incorporation and a place that is the functional equivalent of the principal place of business. The opinion can thus be read as authority both for and against general jurisdiction in North Carolina over a corporation like Goodyear USA $^{16}$ that operates factories and maintains extensive permanent sales facilities in North Carolina. ${ }^{17}$

Part II provides historical context by reviewing the evolution of the Supreme Court's decisions requiring contacts or activity as the basis for jurisdiction over corporations. This Part considers the typology of cases that establishes the starting point for the systematic distinction between general and specific jurisdiction.

Part III discusses the Court's decisions on general jurisdiction before Goodyear Dunlop Tires. This Part shows how the Court has decided cases narrowly to avoid confronting a range of corporate activity that challenges the jurisdictional elements of presence and contacts.

Part IV explores the Court's treatment of general jurisdiction in Goodyear Dunlop Tires. It first explains how the opinion can be read in two different ways. It then proposes a middle path that provides a fair reading of the opinion to avoid the narrowest and broadest possible constructions.

Part V considers practical implications of the Goodyear Dunlop Tires decision and discusses its application in a number of recurring fact situations. It shows how the decision closes the door on a few forms of general jurisdiction but opens new opportunities for expanding general jurisdiction by inviting arguments that a nonresident defendant has lost its status as foreign and become "at home” for purposes of litigation.

While the Court achieved consensus on formal rules when those rules limit general personal jurisdiction, the consensus is unstable. The Court's contemporaneous restriction of specific personal jurisdiction in Nicastro creates new incentives for plaintiffs to invoke general jurisdiction. This will require lower courts to confront-sooner rather than later-issues left unresolved by the Goodyear Dunlop Tires decision and its broad opinion.

16. Goodyear USA was the parent company to petitioners Goodyear Luxembourg Tires, SA, Goodyear Lastikleri T.A.S., and Goodyear Dunlop Tires France, SA. Id. at 2851-52.

17. The first question that Justice Ginsburg posed during oral argument concerned the grounds for jurisdiction over Goodyear USA. See Transcript of Oral Argument at 4, Goodyear Dunlop Tires, 131 S. Ct. 2846 (2011) (No. 10-76). Nevertheless, the opinion does not address the issue. See infra Part V.B.3. 


\section{EVOLUTION OF CONTACTS OR ACTIVITY AS THE BASIS FOR PERSONAL JURISDICTION}

This Part discusses the evolution of modern contacts-based limits on personal jurisdiction. It examines leading cases that establish the common principles of personal jurisdiction widely shared by members of the Court.

\section{A. Pennoyer v. Neff}

Pennoyer v. Neff announced that the Due Process Clause prevents a state from enforcing its own default judgment that was recovered in an action in personam against a nonresident who did not appear in the state and who received only constructive service of process through notice published in a newspaper. ${ }^{18}$ The opinion committed the Court to imposing due process restrictions on state court jurisdiction and introduced a territorial theory of jurisdiction grounded on the twin propositions that (1) a state has "exclusive jurisdiction and sovereignty over persons and property within its territory" and (2) "the laws of one State have no operation outside of its territory ... [and] no tribunal established by it can extend its process beyond that territory so as to subject either persons or property to its decisions." ${ }^{19}$ The opinion approved of a sovereign's jurisdiction over all residents and over any nonresidents who consent to jurisdiction. ${ }^{20}$ It approved of the exercise of

18. 95 U.S. 714, 719-20, 736 (1877). But see Patrick J. Borchers, The Problem with General Jurisdiction, 2001 U. CHI. LEGAL F. 119, 121 (arguing that grounding limits on personal jurisdiction in the Constitution is an "unfortunate mistake").

19. Pennoyer, 95 U.S. at 722 (citing JosePh StORY, COMMENTARIES ON THE CONFLiCT OF LAWs §§ 539-41, 543 (Boston 1834)). Justice Field, writing for the Court in Pennoyer, derived the two regulatory principles from doctrines of public law found in Story's treatise that were based in turn on civil law authorities. See generally STORY, supra, §§ 530-37 (discussing authorities). The Court in Pennoyer applied these two principles to hold that attachment of property to satisfy a judgment could not occur before a party acquired the property. Pennoyer, 95 U.S. at 727-28 (finding that "the jurisdiction of the court to inquire into and determine [a non-resident's] obligations at all is only incidental to its jurisdiction over the property"). It is not obvious why the territorial focus should be on the location of the person at the time of the original service of process.

The Court explained that the default judgment "if void when rendered, will always remain void.” Id. at 728. Professor Linda J. Silberman observes that the holding in Pennoyer "that the Oregon court could not exercise jurisdiction over Neff's property because it had not been attached at the outset of the action... is difficult to reconcile... with the theory underlying [the holding]." Linda J. Silberman, Shaffer v. Heitner: The End of an Era, 53 N.Y.U. L. REv. 33, 45 (1978) (citing Pennoyer, 95 U.S. at 727-28); see also infra note 27.

20. Pennoyer, 95 U.S. at 733. 
jurisdiction over defendants who personally receive service of process in the forum state. ${ }^{21}$ It also permitted jurisdiction over nonresidents sued by state citizens to determine the status of the citizens towards a nonresident, ${ }^{22}$ over nonresident business associations making contracts enforceable in the state, and over corporations created by the law of the state. $^{23}$

Pennoyer adopted a form of substantive due process reasoning that later fell out of favor. Though the Court expressed particular concern with the dangers of fraud that could result from the cross-jurisdictional enforcement of default judgments without notice, ${ }^{24}$ it had already limited such abuses by holding that sister states need not give full faith and credit to judgments rendered without personal jurisdiction, ${ }^{25}$ and lack of jurisdiction was an established ground for refusing to recognize foreigncountry judgments. ${ }^{26}$

It is late in the day to argue that the Court wrongly decided Pennoyer or that due process should impose no greater restrictions on states' exercise of personal jurisdiction than exist under international law. But inasmuch as the Court has still not elaborated a coherent theory of personal jurisdiction, is not too late to acknowledge problematic aspects of the seminal decision, ${ }^{27}$ to reconsider the proper role of international

21. Id.

22. Id. at 734 .

23. Id. at 735. The Court explained:

Nor do we doubt that a State, on creating corporations or other institutions for pecuniary or charitable purposes, may provide a mode in which their conduct may be investigated, their obligations enforced, or their charters revoked, which shall require other than personal service upon their officers or members. Parties becoming members of such corporations or institutions would hold their interest subject to the conditions prescribed by law.

$I d$. at 735-36. The "State" that the opinion refers to is the state of incorporation; however, the Court's underlying reasoning applies with equal force to any state that recognizes the existence of the corporate form as a legal person. See infra note 73 and accompanying text.

24. Id. at 728.

25. Id. at 729. The Full Faith and Credit Clause implementing statute, 28 U.S.C. § 1738 (2006), "appli[es] only when the court rendering the judgment had jurisdiction of the parties and of the subject-matter.” Pennoyer, 95 U.S. at 729 (citing M’Elmoyle v. Cohen, 38 U.S. (13 Pet.) 312 (1839)).

26. See STORY, supra note 19 , $\S 586$ ("In order [to recognize a foreign country judgment], it is indispensable to establish, that the court pronouncing [the] judgment had a lawful jurisdiction over the cause, and the parties.”).

27. Justice Hunt wrote a lengthy dissent. The decision provided one of the four occasions on which wrote in dissent. His chief objection was that the decision unnecessarily focuses on the timing of the attachment:

Whether the property of such non-resident shall be seized upon attachment as the commencement of a suit which shall be carried into judgment and execution, upon which 
norms and legislative authority in construing due process limits on state courts, and to question whether constitutional limits on personal jurisdiction prevent the taking of property without due process or protect fundamental liberty interests. ${ }^{28}$

\section{B. International Shoe Co. v. Washington: Minimum Contacts, Fair Play, and Substantial Justice}

\section{The Back Story}

By the 1950s, International Shoe Co. had become the largest shoe business in the world. ${ }^{29}$ Incorporated in Delaware, ${ }^{30}$ its corporate offices occupied a ten-story structure in downtown St. Louis, ${ }^{31}$ and its extensive warehouse and distribution operations were housed in the sprawling complex of a former brewery in St. Louis. ${ }^{32}$ Absorbing other businesses and brands, the corporation expanded to include other manufacturing and retail operations across the country. ${ }^{33}$

International Shoe Co. did not operate plants or stores in the State of Washington. $^{34}$ But even in that remote northwest corner of the country, it sold enough shoes to employ eleven to thirteen full-time salesmen. ${ }^{35}$

it shall then be sold, or whether it shall be sold upon an execution and judgment without such preliminary seizure, is a matter not of constitutional power, but of municipal regulation only.

Pennoyer, 95 U.S. at 737-38 (Hunt, J., dissenting). Justice Hunt emphasized that the case did not involve a full faith and credit issue and questioned the conclusion that the Constitution required treating the resulting judgment as void, as opposed to erroneous. Id. at 741, 746 . He saw the attachment as involving not a deprivation of individual liberty but a taking of property without due process. Id. at 741 .

28. See infra note 228.

29. International Shoe Co. was already the largest shoe manufacturer in the world when it acquired Florsheim Shoes in 1953. See Christopher D. Cameron \& Kevin R. Johnson, Death of a Salesman? Forum Shopping and Outcome Determination Under International Shoe, 28 U.C. DAVIS L. REV. 769, 796-97 (1995). For an excellent discussion of the history of the defendant and details of the procedure of the litigation, see id. at 786-97.

30. Int'l Shoe Co. v. Washington, 326 U.S. 310, 313 (1945).

31. Built originally for Roberts Shoe Company in 1910, the handsome structure, designed by prominent architect Theodore C. Link, received an art nouveaux face lift to inscribe the International Shoe corporate logo during the 1930s. See 1501 Washington Avenue, BUILT ST. LouIS, http://www.builtstlouis.net/washington/14a.html (last visited Dec. 15, 2011).

32. See Int'l Shoe, 326 U.S. at 313. International Shoe Co. moved its distribution operations to the former brewery in 1922. See History of the Lemp Brewery Complex, HISTORIC LEMP BREWERY, LLC, http://www.lempbrewery.net/history.html (last visited Apr. 5, 2012).

33. Int'l Shoe, 326 U.S. at 313.

34. Id.

35. Id. 
When the State of Washington sought to levy a tax on the corporation for contributions to the state unemployment compensation fund, the corporation challenged the state's personal jurisdiction. ${ }^{36}$

International Shoe represents the rare case where all judges in the courts below and all Justices on the Supreme Court agreed: Washington's exercise of personal jurisdiction was constitutional. ${ }^{37}$ For two generations, courts had applied Pennoyer's conceptual scheme of presence or consent to support personal jurisdiction over nonresident corporations when they engaged in business in the forum state. ${ }^{38}$ Washington state statutes authorized "personal service [on] the employer if found []in the state, or, if not..., by mailing... notice to the employer['s] . . . last known address." "39 Accordingly, the state achieved in-state service on a sales solicitor employed by International Shoe Co., ${ }^{40}$ and this would satisfy Pennoyer's requirements, ${ }^{41}$ so long as the corporate employer engaged in a sufficient level of business in the state. $^{42}$ International Shoe Co.'s supervision of a dozen full-time salesmen and the company's shipments of trainloads of shoes to Washington certainly satisfied the existing level of presence required for personal jurisdiction. ${ }^{43}$

What was novel was the defendant's effort to structure its legal relations so as to avoid having a legal presence in the State of Washington. International Shoe Co. did not authorize its agents to enter into contracts, collect bills, or do anything more than exhibit sample merchandise and forward orders to the office in St. Louis. ${ }^{44}$ The

36. Id. at 311-12, 315-16.

37. Id. at 321.

38. Pennoyer v. Neff, 95 U.S. 714, 733, 735 (1877).

39. Int'l Shoe, 326 U.S. at 312.

40. Id.

41. See id. at 316 (citing Pennoyer, 95 U.S. at 733) (“[The defendant's] presence within the territorial jurisdiction of [the] court was [a] prerequisite to its rendition of a judgment personally binding him.”); see also supra note 21 and accompanying text.

42. See id. at 319.

It is evident that the criteria by which we mark the boundary line between those activities which justify the subjection of a corporation to suit, and those which do not, cannot be simply mechanical or quantitative. The test is not merely ... whether the activity, which the corporation has seen fit to procure through its agents in another state, is a little more or a little less.

Id. (citing St. Louis Sw. Ry. Co. of Tex. v. Alexander, 227 U.S. 218, 228 (1913); Int'l Harvester Co. of Am. v. Kentucky, 234 U.S. 579, 589 (1914)).

43. Id. at 320 .

44. Id. at 314. The Court describes the corporation's business practices in detail. Id. Many of the practices appear to have been motivated by the goal of avoiding a sufficient presence in the state 
soliciting agents received commission. ${ }^{45}$ Further, the corporation did not own any property in Washington, though it authorized its agents to rent both hotel rooms and sample rooms. ${ }^{46}$

In International Shoe, Chief Justice Stone acknowledged that Pennoyer required the defendant to be present in the forum state's territory before a judgment could be valid and "personally binding" on the defendant. ${ }^{47}$ He ultimately linked this requirement to the fact that common law actions had traditionally commenced with the judicial seizure of the defendant's person through a writ of capias ad respondendum or similar process. ${ }^{48}$ The Chief Justice observed:

[N]ow that the capias ad respondendum has given way to personal service of summons or other form of notice, due process requires only that in order to subject a defendant to a judgment in personam, if he be not present within the territory of the forum, he have certain minimum contacts with it such that the maintenance of the suit does not offend "traditional notions of fair play and substantial justice.",49

Chief Justice Stone then explained that the contacts requirement helped avoid the circularity inherent in discussions of corporate presence. $^{50}$ Due process requirements "may be met by such contacts of the corporation with the state of the forum as to make it reasonable, in

to support personal jurisdiction. But there were independent business reasons for providing salesmen with small quantities of samples and separate legal motives for structuring sales so that acceptance occurred in Missouri. Doing so assured that Missouri substantive law applied in an era before parties routinely included choice-of-law provisions in written agreements. See Michael H. Hoffheimer, Conflicting Rules of Interpretation and Construction in Multi-Jurisdictional Disputes, 63 RutGeRs L. REV. 599, 614-17 (2011).

45. Int'l Shoe, 326 U.S. at 314.

46. Id. at 313 .

47. Id. at 316 (citing Pennoyer, 95 U.S. at 733).

48. Id.

49. Id. (quoting Milliken v. Meyer, 311 U.S. 457, 463 (1940)). In Milliken, the Court held that a state could exercise personal jurisdiction over a domiciliary so long as the substituted service provided a method of notice that "is reasonably calculated to give him actual notice of the proceedings and an opportunity to be heard. If it is, the traditional notions of fair play and substantial justice implicit in due process are satisfied.” Milliken, 311 U.S. at 463 (citations omitted) (citing McDonald v. Mabee, 243 U.S. 90 (1917)).

50. Int'l Shoe, 326 U.S. at 316-17 ("To say that the corporation is so far 'present' there as to satisfy due process requirements ... is to beg the question to be decided. For the terms 'present' or 'presence' are used merely to symbolize those activities of the corporation's agent within the state which courts will deem to be sufficient to satisfy the demands of due process." (citing Hutchinson v. Chase \& Gilbert, Inc. 45 F.2d 139, 141 (2d Cir. 1930))). 
the context of our federal system of government, to require the corporation to defend the particular suit which is brought there." 51

\section{The Typology of Cases}

In determining whether corporate activity satisfied the presence required by Pennoyer, the Court emphasized the need to consider the actual burden-“inconveniences"-that the corporation would experience if it litigated in the forum. ${ }^{52}$ The Court then sought to harmonize its new approach with prior cases. It arranged its discussion of prior cases under four distinct categories, each involving different forms of "presence" or "activity." 53

The first category involves jurisdiction claims arising out of corporation's continuous and systematic contacts in the state. These cases were the easiest to decide. The Court explained:

'Presence' in the state [sufficient for personal jurisdiction] has never been doubted when the activities of the corporation there have not only been continuous and systematic, but also give rise to the liabilities sued on, even though no consent to be sued or authorization to an agent to accept service of process has been given. ${ }^{54}$

The second category involves jurisdiction based on the casual presence of an agent or a single isolated act unrelated to the claims in litigation. This type of case was also easily decided. The Court explained "that the casual presence of the corporate agent or even his conduct of single or isolated items of activities in a state in the corporation's behalf are not enough to subject [the corporation] to suit on causes of action unconnected with the activities there."55 In considering

51. Id. at 317 .

52. Id. (quoting Hutchinson, 45 F.2d at 141). Chief Justice Stone wrote that "[a]n 'estimate of the inconveniences' which would result to the corporation from a trial away from its 'home' or principal place of business is relevant in this connection." Id. (quoting Hutchinson, 45 F.2d at 141). From this context, it is unclear whether the Chief Justice used "or" disjunctively in this passagewhether he meant "home" to signify the principal place of business or some place other than the principal place of business.

53. Id. at 317-18.

54. Id. at 317 (citing Int'l Harvester Co. of Am. v. Kentucky, 234 U.S. 579 (1914); St. Louis Sw. Ry. Co. of Tex. v. Alexander, 227 U.S. 218 (1913); Commercial Mut. Accident Co. v. Davis, 213 U.S. 245, 255-56 (1909); Pa. Lumberman's Mut. Fire Ins. Co. v. Meyer, 197 U.S. 407, 414-15 (1905); Conn. Mut. Life Ins. Co. v. Spratley, 172 U.S. 602, 610-11 (1899); St. Clair v. Cox, 106 U.S. 350, 355 (1882)).

55. Id. (citing Old Wayne Mut. Life Ass'n of Indianapolis v. McDonough, 204 U.S. 8, 21 
the burden of litigating in a forum where the corporation had only a casual presence or isolated contact, the Court indicated that it would not limit the point of reference solely to the corporation's principal place of business. $^{56}$ Rather, it would consider all other places where the corporation had more extensive contacts because " $[t]$ o require the corporation in such circumstances to defend the suit away from its home or other jurisdiction where it carries on more substantial activities has been thought to lay too great and unreasonable a burden on the corporation to comport with due process."

The third category involves jurisdiction based on continuous and substantial corporate activity entirely distinct from the causes of action. The Court conceded that it had held that "continuous activity of some sorts within a state" was insufficient to support jurisdiction over corporations in "suits unrelated to that activity."58 But only one case cited was decided on constitutional grounds. ${ }^{59}$ Rather than closely

(1907); Cox, 106 U.S. at 359-60; Frere v. Louisville Cement Co., 134 F.2d 511, 515 (D.C. Cir. 1943)).

56. Id.

57. Id.

58. Id. The Chief Justice cited five cases where some level of continuous activity was insufficient to support general jurisdiction. Four out of five cases were not decided on constitutional grounds. See id. (citing Davis v. Farmers Coop. Equity Co., 262 U.S. 312, 317 (1923); People’s Tobacco Co. v. Am. Tobacco Co., 246 U.S. 79, 85-86 (1918); Simon v. S. Ry. Co., 236 U.S. 115, 132 (1915); Green v. Chi., Burlington \& Quincy Ry. Co., 205 U.S. 530, 533-34 (1907); Old Wayne Mut. Life, 204 U.S. at 21, 27). The cases document the paucity of authority under the Due Process Clause for invalidating jurisdiction over corporations engaging in some level of business activity.

Davis held that the Commerce Clause, not the Due Process Clause, prevented an exercise of general jurisdiction over a railroad based on activity of its in-state agent who had authority only to solicit out-of-state business. Davis, 262 U.S. at 315-17. People's Tobacco construed a federal statute requiring service on a defendant who "resides or is found" in a federal district as requiring presence of corporate officers or agents carrying on business for the corporation. People's Tobacco, 246 U.S. at 84 (quoting 15 U.S.C. § 7 (2006)). Simon held that a judgment creditor could be enjoined from enforcing a state judgment where jurisdiction was obtained by service on statutory agents but where the claims did not relate to the corporate defendant's business in the state. Simon, 236 U.S. at 130, 132. The Court apparently understood itself to be applying federal general equity principles, finding that fraud and equity supported the injunction judgment against enforcing a null judgment. See id. at 122 ("United States courts, by virtue of their general equity powers, had jurisdiction to enjoin [a] plaintiff from enforcing a judgment" obtained by fraud and to "enjoin parties from enforcing [judgments] obtained without service”). Green held as a matter of federal common law that the validity of jurisdiction based on personal service on a corporate agent in a district depended on whether the corporation was doing business in the district. Green, 205 U.S. at 533-34.

59. Only one case was decided on constitutional grounds: Old Wayne Mutual Life Ass'n held that the Due Process and Full Faith and Credit Clauses required reversal of an Indiana Supreme Court decision enforcing a Pennsylvania default judgment against an Indiana insurance corporation based on a policy issued to Pennsylvania residents to insure the life of a Pennsylvania resident. Old Wayne Mut. Life Ass'n, 204 U.S. at 12-13, 23. Giving conclusive effect to a standard choice of law 
examine the facts of those cases, the Court asserted that the decisions nonetheless comported with the exercise of jurisdiction when the defendant engaged in substantial activity. ${ }^{60}$ "[T] $]$ here have been instances in which the continuous corporate operations within a state were thought so substantial and of such a nature as to justify suit against [the corporation] on causes of action arising from dealings entirely distinct from those activities." 61

The fourth and final category involves claims of single occasional acts by a corporate agent within the state. Sometimes these acts were insufficient for personal jurisdiction, but sometimes, "because of their nature and quality and the circumstances of their commission, [they were] deemed sufficient to render the corporation liable to suit." ${ }^{\prime 62}$

From the opinion's discussion of the four kinds of cases, scholars later constructed a typology of cases into general and specific jurisdiction. $^{63}$ But Chief Justice Stone did not originally promulgate the types of cases as four exclusive categories. Rather he treated them as pairs of extremes. Thus, continuous and systematic activity giving rise to the claim was one extreme that supported jurisdiction, while an isolated contact unconnected to corporate activity in the state was the other extreme that clearly did not support jurisdiction. ${ }^{64}$ Falling within

clause stating that the policy was governed by Indiana law, the Court found both that the policy sold to Pennsylvania residents did not constitute doing business in Pennsylvania and that, despite evidence of other business activity, issuing the policy did not support personal jurisdiction relating to business not transacted in the state. Id. at 21-22. This outrageous decision may be partly explained by the fact that counsel for the judgment creditor never appealed or filed a brief to the Court.

60. Int'l Shoe, 326 U.S. at 318 (citing Mo., Kan. \& Tex. Ry. Co. v. Reynolds, 255 U.S. 565 (1921) (per curiam); St. Louis Sw. Ry. Co., 227 U.S. 218; Tauza v. Susqehanna Coal Co., 115 N.E. 915 (N.Y. 1917)).

61. Id. (citing Mo., Kan. \& Tex. Ry., 255 U.S. 565; St. Louis Sw. Ry., 227 U.S. 218; Tauza, 115 N.C. 915).

62. Id. (citing Young v. Masci, 289 U.S. 253 (1933); Hess v. Pawloski, 274 U.S. 352 (1927); Kane v. New Jersey, 242 U.S. 160 (1916)). In the context of this last classification, the Court emphasized the benefit of replacing the search for fictional or metaphorical "presence" or constructive "consent" by a direct evaluation of the underlying activity. Id. at 318-19.

True, some of the decisions holding the corporation amenable to suit have been supported by resort to the legal fiction that it has given its consent to service and suit, consent being implied from its presence in the state through the acts of its authorized agents. But more realistically it may be said that those authorized acts were of such a nature as to justify the fiction.

Id. (citation omitted).

63. See von Mehren \& Trautman, supra note 3, at 1136.

64. See Int'l Shoe, 326 U.S. at 319 (stating that personal jurisdiction cannot exist when "the state has no contacts, ties, or relations to the defendant," but acknowledging the presence of personal jurisdiction for "obligations aris[ing] out of or [in] connect[ion] with the activities within the state"). 
these extremes were many more difficult cases-including the single isolated act that sometimes did and sometimes did not support jurisdiction. ${ }^{65}$ The Court's new "minimum contacts" requirement added little more than the appropriate label when a court decided that a case satisfied constitutional requirements. ${ }^{66}$

International Shoe substituted a more flexible, policy-oriented analysis for the conceptualism of Pennoyer. ${ }^{67}$ The Court identified meaningful contacts in the state that occurred during the course of the defendant's business. ${ }^{68}$ Regardless of how International Shoe Co. sought to structure its legal relations to avoid "presence" in a state, the important point was that vast numbers of its shoes were shipped into the state as a result of the salesmen's in-state activities. ${ }^{69}$

\section{3. "Fair Play and Substantial Justice” Restrictions on Jurisdiction}

In hindsight, International Shoe authorized an expansion of the permissible scope of state long-arm jurisdiction by substituting a flexible evaluation of contacts and fairness for the "presence" previously required. ${ }^{70}$ At the time, however, the meaning of the Court's decision was less certain. While every member of the Court agreed that personal jurisdiction over International Shoe Co. was constitutional, Justice Black

65. See, e.g., Rosenberg Bros. \& Co. v. Curtis Brown Co., 260 U.S. 516, 517-18 (1923) (providing an example of a single isolated act that did not support jurisdiction).

66. See generally Douglas D. McFarland, Drop the Shoe: A Law of Personal Jurisdiction, 68 Mo. L. REV. 753, 761-70 (2003) (criticizing the minimum contacts test); Kevin C. McMunigal, Essay, Desert, Utility, and Minimum Contacts: Toward a Mixed Theory of Personal Jurisdiction, 108 YALE L.J. 189, 189 (1998) (arguing that the minimum contacts test is ambiguous and incoherent).

67. McFarland, supra note 66, at 778 (arguing that International Shoe led courts to decide merely whether jurisdiction was fair or unfair).

68. See Int'l Shoe, 326 U.S. at 313-14, 320.

69. Id. at 320 .

70. Justice Scalia explained the history of cases after International Shoe as permitting deviations from traditional restrictions on personal jurisdiction "but only with respect to suits arising out of the absent defendant's contacts with the State.” Burnham v. Superior Court, 495 U.S. 604, 610 (1990) (plurality opinion) (citing Helicopteros Nacionales de Colom., S.A. v. Hall, 466 U.S. 408, 414 (1984)). Twelve years after International Shoe, Justice Black wrote an opinion sustaining California's exercise of personal jurisdiction over a claim arising from a nonresident insurance company sale of one life insurance policy in the state. McGee v. Int'l Life Ins. Co., 355 U.S. 220 (1957). The opinion expressly referred to the judicial trend to expand the reach of personal jurisdiction. Id. at 222 ("Looking back over this long history of [personal jurisdiction decisions,] a trend is clearly discernible toward expanding the permissible scope of state jurisdiction over foreign corporations and other nonresidents. In part this is attributable to the fundamental transformation of our national economy ....”). 
wrote separately to express concern that the new policy-oriented approach could restrict state power over a nonresident corporation doing business in the state. ${ }^{71}$ For Justice Black, a nonresident corporation engages in activity in a state only by grace of the state's law, and the state may condition its recognition of the corporation on the corporation's consent to jurisdiction in the state's court. ${ }^{72}$ While Justice Black's vision of state power lost traction over time, ${ }^{73}$ his warning that International Shoe's approach could reduce as well as expand personal jurisdiction was prescient. $^{74}$

\section{GENERAL JURISDICTION BEFORE GOODYEAR DUNLOP TIRES}

\section{A. In Rem Cases After International Shoe}

In Pennoyer v. Neff, the Court had expressly approved of the exercise of jurisdiction in rem, a form of personal jurisdiction established by the judicial seizure of property at the commencement of the lawsuit. ${ }^{75}$

71. Int'l Shoe, 326 U.S. at 324 (Black, J., concurring) ("I believe that the Federal Constitution leaves to each State, without any 'ifs' or 'buts,' a power to tax and to open the doors of its courts for its citizens to sue corporations whose agents do business in those States.”). Justice Black cautioned that the Court's references to fairness and convenience might equally support restrictions on state jurisdiction. Id. at 324-25.

I think it a judicial deprivation to condition its exercise upon this Court's notion of "fair play," however appealing that term may be. Nor can I stretch the meaning of due process so far as to authorize this Court to deprive a State of the right to afford judicial protection to its citizens on the ground that it would be more "convenient" for the corporation to be sued somewhere else.

Id.

72. Id. at 323 .

73. "[T] $]$ he old notion that a state could entirely exclude corporations or condition their entry upon consent to jurisdiction because corporations were state-created legal entities that could not operate beyond a sovereign's borders eroded long ago.” Brilmayer et al., supra note 12, at 759 (footnote omitted) (citing Pensacola Tel. Co. v. W. Union Tel. Co., 96 U.S. 1, 10-12 (1877); Bank of Augusta v. Earle, 38 U.S. (13 Pet.) 519, 587 (1839)). A state may not entirely disregard the existence of corporations created under foreign law, but a state may apply its law and its choice-oflaw rules to determine the rights and liabilities of foreign corporations to third persons affected by corporate behavior in the state. E.g., WiLliam M. RICHMAN \& William L. REYNOLDS, UNDERSTANDING CONFLICT OF LAWS § 91, at 288 (3d ed. 2002); KERMIT ROOSEVELT III, CONFLICT OF LAWS 14 (2010).

74. Int'l Shoe Co., 326 U.S. at 326 (Black, J., concurring) ("True, the State's power is here upheld. But the rule announced means that tomorrow's judgment may strike down a State or Federal enactment on the ground that it does not conform to this Court's idea of natural justice.”). Over thirty years later, the Court applied the minimum contacts test to invalidate a state's exercise of personal jurisdiction. Shaffer v. Heitner, 433 U.S. 186, 216-17 (1977); see infra notes 79-84 and accompanying text.

75. 95 U.S. 714, 723 (1877) (“[T]he State, through its tribunals, may subject property situated 
During the twentieth century, the Court encouraged the creative extension of in rem jurisdiction, and it became possible for a creditor to obtain in rem jurisdiction by attaching a debt in any state where the debtor was physically present. ${ }^{76}$ Though controversial, ${ }^{77}$ the certainty provided by attachment and the presence of assets sufficient to satisfy a judgment led in rem jurisdiction to become the judicially preferred method for prosecuting claims against foreign corporations. ${ }^{78}$

When the exercise of jurisdiction in rem did not arise out of or relate to the attached property, it supported a form of limited general jurisdiction. $^{79}$ In 1977, the Supreme Court restricted effective general jurisdiction by attachment. It held unanimously in Shaffer v. Heitner that actions in rem must satisfy the same constitutional requirements of minimum contacts and traditional notions of fair play and substantial justice that the Court imposed for in personam cases. ${ }^{80}$ This holding did

within its limits owned by non-residents to the payment of the demand of its own citizens against them; and the exercise of this jurisdiction in no respect infringes upon the sovereignty of the State where the [nonresident] owners are domiciled.”). For good measure, the Court also endorsed the constitutional sufficiency of notice by constructive service by publication in such actions in rem. Id. at 727.

76. Harris v. Balk, 198 U.S. 215, 222-23 (1905).

77. Justices Harlan and Day dissented without opinion. Id. at 228.

78. See, e.g., Perkins v. Benguet Consol. Mining Co., 132 P.2d 70 (Cal. Dist. Ct. App. 1942). In Perkins, California courts exercised in rem jurisdiction over a Philippine association that maintained a bank account in the state. Id. at 78. The location of assets in the state allowed the court to overlook the actual legal identity of the owner-treated for purposes of the litigation as a corporation-and to overlook whether the funds attached were related to the claims. Id. at 76 . Although the defendant raised many legal obstacles to paying dividends and challenged jurisdiction in related cases, it apparently did not consider challenging the California court's in rem jurisdiction. See Perkins v. Benguet Consol. Mining Co., 342 U.S. 437, 438-39 (1952). After the decision in California, Benguet moved its assets to Ohio and deposited them in the name of the corporation's president in two banks. Perkins v. Benguet Consol. Mining Co., 95 N.E.2d 5, 8 (Ohio Ct. App. 1950) (per curiam), aff'd 98 N.E.2d 33 (Ohio 1951), vacated, 342 U.S. 437. For further discussion, see infra Part III.B.1.

79. See von Mehren \& Trautman, supra note 3, at 1136. Such jurisdiction affects the defendant's rights only up to the value of the interest in the asset seized. See id. at 1136, 1139-40.

When scholars state that "[t]he Supreme Court has addressed directly ... general jurisdiction" on only two occasions since International Shoe, they reveal how the term "general jurisdiction" has become synonymous with the original idea of unlimited general jurisdiction. See, e.g., B. Glenn George, In Search of General Jurisdiction, 64 TuL. L. REv. 1097, 1108-09 (1990).

80. 433 U.S. 186, 212 (1977) ("We therefore conclude that all assertions of state-court jurisdiction must be evaluated according to the standards set forth in International Shoe and its progeny.”). The broadly written opinion clarifies that the same constitutional requirement applied to all forms of personal jurisdiction.

Although Justice Brennan published a concurring and dissenting opinion agreeing with the Court's conclusion that actions in rem must meet International Shoe's requirement of minimum contacts, he disagreed with the Court's conclusion that such contacts were not established. Id. at 220-21, 227-28 (Brennan, J., concurring in part and dissenting in part). 
not alter the reach of in rem jurisdiction when the legal claims related to attached property, ${ }^{81}$ but it meant that so-called quasi in rem jurisdiction was no longer permissible when the defendant had no ties in the state and when the claims in litigation were unrelated to the property that had been seized to secure jurisdiction. ${ }^{82}$ In other words, Shaffer restricted the permissible scope of quasi in rem jurisdiction to the scope of specific jurisdiction. ${ }^{83}$ Further consequences of Shaffer's holding have been questioned. $^{84}$

81. See id. at 207 (majority opinion) (quoting RESTATEMENT (SECOND) OF CONFLICT OF LAWS $\S 56$ intro. note (1971)) (internal quotation marks omitted). Similarly, "[t]he presence of property may also favor jurisdiction in cases, such as suits for injury suffered on the land of an absentee owner, where the defendant's ownership of the property is conceded but the cause of action is otherwise related to rights and duties growing out of that ownership." Id. at 208.

82. Id. at 208-09 ("For the type of quasi in rem action typified by [Shaffer], however, accepting the proposed analysis would result in significant change.... [T] he presence of the property alone [absent minimum contacts] would not support the State's jurisdiction.”).

83. See von Mehren \& Trautman, supra note 3, at 1136 (noting that "affiliations between the forum and underlying controversy normally support" specific jurisdiction). The Court applied Shaffer to invalidate the emerging practice of attaching a tortfeasor's insurance policy by serving the insurer at its place of business, a device that effectively allowed jurisdiction in many states where the tortfeasor had no presence or contacts. Rush v. Savchuk, 444 U.S. 320, 327-28, 332-33 (1980). For a discussion of quasi in rem cases in the context of general jurisdiction, see Brilmayer et al., supra note 12, at 760-62. Silberman argues that the connection between a state and a defendant doing business in the state in cases like Rush satisfied modern theories of jurisdiction better than the attachment theory of jurisdiction. Silberman, supra note 19, at 50-51 \& n.79. Other scholars observed that the Court never satisfactorily explained why such quasi in rem actions deserved different treatment from direct actions. RUSSELL J. WEINTRAUB, COMMENTARY ON THE CONFLICT OF LAWS § 4.29, at 286 (6th ed. 2010).

While Rush clarified the relatedness requirement for specific jurisdiction, 444 U.S. at 328-29, traditional quasi in rem jurisdiction did not arise from disputes between insurer and insured. Quasi in rem jurisdiction of this type was first found in Selder v. Roth, 216 N.E.2d 312, 314-15 (N.Y. 1966), abrogated by Rush, 444 U.S. 320. The court required the insurer to defend in New York "not because a debt owing by it to the defendant ha[d] been attached but because by its policy it ha[d] agreed to defend in any place where jurisdiction [was] obtained against its insured.” Id. at 315. Accordingly, this form of jurisdiction would not have been presumptively constitutional under Justice Scalia's approach in Burnham. See Burnham v. Superior Court, 495 U.S. 604, 619 (1990) (plurality opinion) ("The short of the matter is that jurisdiction based on physical presence alone constitutes due process because it is one of the continuing traditions of our legal system that define the due process standard ....”).

84. Justice Stevens concurred because application of the decision in other contexts was "not entirely clear.” Shaffer, 433 U.S. at 219 (Stevens, J., concurring). Justice Powell concurred but implicitly disagreed that limited general jurisdiction based on "property whose situs is ... located within a State may, without more, provide the contacts necessary to subject a defendant to jurisdiction within the State.” Id. at 217 (Powell, J., concurring); see also Burnham, 495 U.S. at 621-22 (limiting Shaffer's holding to quasi in rem cases and observing that traditional forms of personal jurisdiction are presumptively constitutional). But see id. at 629-30 (Brennan, J., concurring) (citing Shaffer, 433 U.S. at 212) (reaffirming Shaffer's statement that all forms of jurisdiction must satisfy contemporary notions of due process under International Shoe). 


\section{B. In Personam General Jurisdiction Cases After International Shoe}

\section{Perkins v. Benguet Consolidated Mining Co.}

The Supreme Court's only decision after International Shoe that permitted the exercise of unlimited general jurisdiction over a corporation is Perkins v. Benguet Consolidated Mining Co. ${ }^{85}$ The unusual facts of the case have produced lingering uncertainty as to its legal significance.

Benguet Consolidated Mining Co. operated gold and silver mines in the Philippines. ${ }^{86}$ During World War II, the corporation ceased its mining operations. ${ }^{87}$ The corporation's president- "who was also [its] general manager and principal stockholder"-returned to his hometown in Ohio where he maintained an office, conducted business for the corporation, and kept corporate records. ${ }^{88}$ The president deposited company funds in Ohio banks, designated an Ohio bank as transfer agent for the corporation's stock, ${ }^{89}$ and paid his own salary and the salaries of two Ohio-based secretaries. ${ }^{90}$ From Ohio, he disbursed funds and later supervised the reconstruction of the foreign mining facilities. ${ }^{91}$ The president organized directors' meetings in Ohio both at his home and office. $^{92}$

As Justice Burton summarized, the corporation had carried on in Ohio "a continuous and systematic, but limited, part of its general business." "93 The action in personam was commenced by service on the corporation's president, an Ohio resident, while engaged in such business

85. 342 U.S. 437, 444-45 (1952).

86. Id. at 439 .

87. Justice Burton, writing for the Court, assumed that the Japanese halted the mining operations. Id. at 447. The state court found only that the corporation's surface operations were completely destroyed; it did not explain how or by whom. Perkins v. Benguet Consol. Mining Co., 95 N.E.2d 5, 8 (Ohio Ct. App. 1950), aff'd, 98 N.E.2d 33 (Ohio 1951), vacated, 342 U.S. 437. Of Benguet's five directors, three suffered internment by the Japanese, and one was killed. Id.

88. Perkins, 342 U.S. at 447-48. The president had a long connection with Clermont County, Ohio, where he had a farm and a personal office at the bank. Perkins, 95 N.E.2d at 7.

89. Perkins, 342 U.S. at 448.

90. Perkins, 95 N.E.2d at 8 . The corporation's funds were moved from California to Ohio where they were held by the president in his own name. Id. at 8 . The president paid himself a salary of $\$ 12,000$ for the year 1945 from the corporate funds that he controlled. Id. at 7.

91. Id.

92. Id. While some directors' meetings were held in Ohio during the war, most were held in locations in the United States outside of Ohio. See id. (noting meetings in Ohio, Washington, New York, and San Francisco).

93. Perkins, 342 U.S. at 438. 
in the state. ${ }^{94}$ The Court found that the president "carried on in Ohio a continuous and systematic supervision of the necessarily limited wartime activities of the company" and concluded that due process did not prohibit Ohio courts from exercising jurisdiction over claims unrelated to the activity. ${ }^{95}$

Perkins presented extreme facts. While the corporation's real property, its mines, remained in the Philippines, the president moved all of its other assets and most, but not all, ${ }^{96}$ of the corporate activity to Ohio. ${ }^{97}$ Nevertheless, the corporation did not reincorporate in Ohio or formally establish a principal place of business there; nor did it appoint an agent for service of process in Ohio. ${ }^{98}$ In addition to the magnitude of corporate activity in Ohio, other consideration supported jurisdiction. The causes of action were related to corporate activity in the state. ${ }^{99}$ The mining company was a foreign corporation ${ }^{100}$ but had attributes of a

94. Id. at 448. It is not clear when service occurred, but it must have happened before early 1948 when the president, at age 80, returned to the Philippines to rebuild the company. See Mining: Return of the King, TIME MAG., Mar. 8, 1948, at 96 (reporting on the president's return to the Philippines), available at http:/www.time.com/time/magazine/article/0,9171,853309,00.html. The Ohio appellate court decision affirming trial court orders quashing service was published January 27, 1950. Perkins, 95 N.E.2d at 5, 12.

Though surface facilities at the mines were destroyed during the war, the corporation began to restore facilities in 1946, purchasing "machinery, supplies and equipment" from funds disbursed from the Ohio accounts. Id. at 8 (internal quotation marks omitted). By late 1948, the corporation employed over 3,000 employees in the Philippines. William R. Sears, A Good Judge of Gold, ROTARIAN, Jan. 1949, at 25, 25.

95. Perkins, 342 U.S. at 448. Chief Justice Vinson joined Justice Minton’s dissent. Id. at 449 (Minton, J., dissenting). Under Ohio law, the state supreme court's syllabus states the law applicable to the case. Id. The Ohio Supreme Court's syllabus, unlike the accompanying opinion, did not identify the Due Process Clause as the ground for the refusal to accept jurisdiction. Perkins v. Benguet Consol. Mining Co., 98 N.E.2d 33, 34 (Ohio 1951), vacated, 342 U.S. 347. The two dissenting Justices concluded that the syllabus left an adequate state law basis for the decision below. Perkins, 342 U.S. at 449-50 (Minton, J., dissenting).

96. “Two or three, out of nine, [directors'] meetings . . . were held at [the president's] home” in Ohio; the others occurred outside of the state. Perkins, 95 N.E.2d at 8 (internal quotation marks omitted).

97. Perkins, 342 U.S. at 447-48.

98. Perkins, 95 N.E.2d at 6-8. The corporation's president may have deliberately sought to avoid having the corporation become subject to personal jurisdiction in any state. See supra notes 78 and 90.

99. The plaintiff sought unpaid dividends and damages resulting from the failure to issue stock certificates. Perkins, 342 U.S. at 439. Although traditionally viewed as a case involving general jurisdiction, one could argue that Ohio could have exercised specific jurisdiction. See Borchers, supra note 18, at 124 (positing that the corporation's Ohio activity was sufficiently related to the claims in the case).

100. Perkins, 342 U.S. at 439. The Supreme Court treated Benguet as a corporation because it concluded that the Ohio Supreme Court had so held. Id. at 439 \& n.2. The Ohio Supreme Court apparently held that the company was a corporation for purposes of litigation, including state service 
partnership under which the president might incur individual liability for corporate debts, making him an appropriate person to receive service. ${ }^{101}$

The Court later described its holding as "permitting general jurisdiction where defendant's contacts with the forum were 'continuous and systematic."”102 Yet in later opinions, the Court reasoned that jurisdiction had been proper because Ohio was the corporation's de facto principal place of business. ${ }^{103}$

\section{Helicopteros Nacionales de Colombia, S.A. v. Hall}

In the wake of Perkins, state courts began to exercise general jurisdiction over foreign corporations with "substantial" activity or "continuous and systematic" business contacts in the state. The Supreme Court of Texas found that a Colombian corporation providing helicopter transportation services in Peru satisfied this level of activity based on purchases in Texas and was thus subject to general jurisdiction for claims completely unrelated to its business in the state. ${ }^{104}$

In Helicopteros Nacionales de Colombia S.A. v. Hall, the Supreme Court reversed the decision of the Texas Supreme Court. ${ }^{105}$ Writing for the majority, Justice Blackmun summarized the defendant's contacts with Texas: (1) Helicol's chief executive officer negotiated the contract

requirements, but it expressly stated that such recognition did not limit shareholder liability. Perkins, 98 N.E.2d at 37-38.

101. Perkins, 342 U.S. at 439-40 (allowing for service of process on the president of the corporation).

102. Calder v. Jones, 465 U.S. 783, 787 (1984) (quoting Perkins, 342 U.S. at 448).

103. See, e.g., Goodyear Dunlop Tires Operations, S.A. v. Brown, 131 S. Ct. 2846, 2856 (2011); Keeton v. Hustler Magazine, Inc., 465 U.S. 770, 779 (1984). Professor Mary Twitchell discusses the different views that emerged surrounding the relationship of Perkins to the Court's general requirement in International Shoe of minimum contacts and fair play. Mary Twitchell, The Myth of General Jurisdiction, 101 HARV. L. REV. 610, 626 n.75 (1988).

104. Hall v. Helicopteros Nacionales de Colom., S.A., 638 S.W.2d 870, 873-74 (Tex. 1982), rev'd, 466 U.S. 408 (1984). The plaintiffs' decedents were killed in a helicopter accident in Peru while working for a joint venture based in Texas. Id. at 870-71. The joint venture had contracted with the defendant, a Colombian corporation commonly known as Helicol, to provide transportation. Id. at 871. The claim was not against the Texas employer but against Helicol, which owned and operated the helicopter. Id. at 870 .

Dissenting members of the Texas Supreme Court partially anticipated the doctrine announced in Goodyear Dunlop Tires. First, they asserted that the substantial and continuous activity required for general jurisdiction requires "some close substantial connection with the state approaching the relationship between the state and its own residents.” Id. at 882-83 (Pope, J., dissenting) (footnote omitted) (citing Perkins, 342 U.S. at 438, 445, 448). Second, they emphasized that factors relevant for a finding of specific jurisdiction are immaterial to a finding of general jurisdiction, which requires a level of substantial and continuous activity. Id.

105. 466 U.S. at 419. 
with the decedents' Texas employer to provide transportation services in South America; (2) Helicol purchased approximately eighty percent of its helicopters and related equipment from Bell Helicopter Company, a manufacturer in Fort Worth, Texas; (3) Helicol sent pilots to Texas for training; (4) Helicol's management and maintenance personnel visited Bell Helicopter's factory in Texas; and (5) Helicol received payments from funds held in a Texas bank. ${ }^{106}$ Justice Blackmun observed that Helicol was not authorized to do business in Texas and never had an agent there for service of process; it performed no helicopter operations in the state and sold no product that reached the state; it solicited no business in Texas, signed no contracts there, had no employees based there, and recruited no employees in the state; it owned no property, maintained no office, and kept no records in the state; and it had no shareholders in the state of Texas. ${ }^{107}$

In the Court's first explicit distinction between specific and general jurisdiction, Justice Blackmun contrasted specific jurisdiction-for which the "relationship among the defendant, the forum, and the

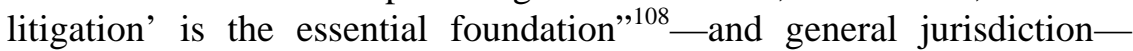
which requires "sufficient contacts between the State and the foreign corporation." 109 The Court then turned to the issue of whether Helicol's contacts with Texas "constitute the kind of continuous and systematic general business contacts the Court found . . in Perkins."110

Dismissing the significance of most of Helicol's activity in Texas, the Court concluded that the temporary presence of the chief executive officer was not continuous and systematic and that the location of the bank from which payments were made was irrelevant. ${ }^{111}$ The Supreme Court of Texas found that Helicol's purchase of over four million dollars worth of equipment and the regular training of pilots constituted sufficient contacts. ${ }^{112}$ The Supreme Court disagreed: "[W]e hold that

106. Id. at 410-11. The parties conceded that the claims did not arise out of or relate to the defendant's activities in Texas. Id. at 415.

107. Id. at 411.

108. Id. at 414 (quoting Shaffer v. Heitner, 433 U.S. 186, 204 (1977)).

109. Id. (citing Perkins v. Benguet Consol. Mining Co., 342 U.S. 437 (1952); Keeton v. Hustler Magazine, Inc., 465 U.S. 770, 779-80 (1984)).

110. Id. at 416 .

111. Id. at 416-17.

112. Hall v. Helicopteros Nacionales de Colom., S.A., 638 S.W.2d 870, 871-72 (Tex. 1982) rev'd, 466 U.S. 408 (1984). The Texas court pointed to an additional fact that the Supreme Court did not discuss - the defendant maintained a permanent employee presence "in Texas on a yearround rotation basis.” Id. at 871 . 
mere purchases, even if occurring at regular intervals, are not enough to warrant a State's assertion of in personam jurisdiction over a nonresident corporation in a cause of action not related to those purchase transactions."

Justice Blackmun's opinion for the Court signaled a commitment to the analytic distinction between specific and general jurisdiction and made clear that general jurisdiction required a much higher level of corporate activity than specific jurisdiction. ${ }^{114}$ It borrowed from Perkins the label of "continuous and systematic" contacts for such activity. ${ }^{115}$ The opinion helpfully explained that "mere purchases," occurring on a regular basis, training, and other visits failed to create sufficiently continuous and systematic contacts to support general jurisdiction. ${ }^{116}$ But it did not explain what other activity, such as regular sales or maintaining some permanent physical presence in the forum, might be enough. $^{117}$

\section{GENERAL JURISDICTION IN GOODYEAR DUNLOP TIRES}

\section{A. Case History}

Julian Brown and Matthew Helms, thirteen-year-old boys residing in North Carolina, died from injuries they received during a trip to France when the bus on which they were riding rolled over. ${ }^{118}$ Administrators of the children's estates commenced a wrongful death action in North Carolina state court, alleging that a defective tire manufactured by Goodyear Turkey caused the rollover. $^{119}$ The action named as

113. Helicopteros, 466 U.S. at 418. Similarly, the Court viewed the regular training of pilots as incidental to the purchases and thus insignificant. Id. The Court relied in part on pre-International Shoe authority that "purchases and related trips" are not sufficient for general jurisdiction. Id. at 417 (citing Rosenberg Bros. \& Co. v. Curtis Brown Co., 260 U.S. 516, 518 (1923)).

114. Id. at $413-18$.

115. Id. at 416 (quoting Perkins v. Benguet Consol. Mining Co., 342 U.S. 437, 445 (1952)).

116. Id. at 418 .

117. The confusing state of the law is evident in the briefing and arguments in Goodyear Dunlop Tires. The petitioners asked the Court to decide on narrow grounds that the North Carolina courts lacked general jurisdiction based on the lack of direct sales and lack of permanent physical presence by corporate agents. Brief for Petitioners at 12, 21, Goodyear Dunlop Tires Operations, S.A. v. Brown, 131 S. Ct. 2846 (2011) (No. 10-76); Transcript of Oral Argument, supra note 17, at 10-11.

118. Brown v. Meter, 681 S.E.2d 382, 385 (N.C. Ct. App. 2009), rev'd sub nom. Goodyear Dunlop Tires Operations, S.A. v. Brown, 131 S. Ct. 2846 (2011).

119. Id. at 384. Plaintiffs' theory was that plies on the tire separated. Id. 
defendants Goodyear Tire and Rubber Company (Goodyear USA) ${ }^{120}$ and three affiliated European corporations, Goodyear France, Goodyear Luxembourg, and Goodyear Turkey. ${ }^{121}$ After limited discovery, the trial court denied the foreign defendants' motions to dismiss for lack of personal jurisdiction. ${ }^{122}$

The state appellate court affirmed. ${ }^{123}$ The applicable long-arm statute $^{124}$ authorized personal jurisdiction so long as it did not violate the Constitution. $^{125}$ Because the wrongful death claims did not arise out of or relate to the defendants contacts in North Carolina, ${ }^{126}$ the appellate court recognized that general personal jurisdiction required a finding that the defendants' maintained sufficiently continuous and systematic activities in North Carolina to support the exercise of general personal jurisdiction. ${ }^{127}$

120. Id. at 384 n.1. The state court opinion did not explain the presence of Goodyear USA, except to observe that Goodyear USA did not challenge the North Carolina court's jurisdiction. See Goodyear Dunlop Tires, 131 S. Ct. at 2850 (noting also that Goodyear USA operates plants in North Carolina and "regularly engaged in commercial activity there"). Goodyear USA is an Ohio corporation qualified to do business in North Carolina where it appointed an agent to receive service of process. Id.; Transcript of Oral Argument, supra note 17, at 4. When asked about the basis for jurisdiction, corporate counsel explained that Goodyear USA consented to jurisdiction. Transcript of Oral Argument, supra note 17, at 4.

121. Brown, 681 S.E.2d at 384 n.1. One party's name changed during litigation. This Article refers to the affiliated corporations by the names employed in the Supreme Court opinion. Goodyear Dunlop Tires, 131 S. Ct. at 2851-52.

122. Brown, 681 S.E.2d at 385, 387. The trial court found it had jurisdiction based on the defendants' "continuous and systematic ties with the State" and concluded that the "[e]xercise of general jurisdiction over the defendants ... $\mathrm{d}[\mathrm{id}]$ not offend traditional notions of fair play and justice." Id. at 387.

Most of the trial court's fact finding was uncontested on appeal. See id. at 392. The appellate court concluded that two findings of fact were not supported. These related to the conclusion that the foreign corporations "caused" tires to be shipped into North Carolina. Id. The appellate court also observed that whether the defendant companies had continuous and systematic contacts or conducted substantial activity in North Carolina were questions of law and not findings of fact. Id.

123. Id. at 395.

124. N.C. GEN. STAT. ANN. § 1-75.4 (2007).

125. See Brown, 681 S.E.2d at 387 (“'When personal jurisdiction is alleged to exist pursuant to the long-arm statute, the question of statutory authority collapses into one inquiry[,]' which is whether defendant has the 'minimum contacts necessary to meet the requirements of due process."” (alteration in original) (quoting Filmar Racing, Inc. v. Stewart, 541 S.E.2d 733, 736 (N.C. Ct. App. 2001))).

126. Id. at 388.

127. Id. Because all parties conceded that the contacts were unrelated to the claims, id., the case did not provide the Supreme Court with an opportunity to decide how closely litigation must be related to the defendant's contacts to establish specific jurisdiction. See generally Brilmayer et al., supra note 12, at 738 (discussing the uncertainty surrounding how closely the defendant's contacts with the forum must relate to the claims in order to support specific jurisdiction and proposing a "test of substantive relevance" under which specific jurisdiction would exist when the jurisdictional 
The court found systematic and continuous contacts based on the corporations' engaging in international business with unlimited geographical scope. ${ }^{128}$ The fact that an allegedly defective tire was marked for sale in the United States persuaded the court that "the manufacturer contemplated that the tire might be sold in this country."129 Further, from 2004 to 2007, North Carolina received shipments of at least 33,923 tires manufactured by Goodyear France, 6,402 tires manufactured by Goodyear Luxembourg, and 4,059 tires manufactured by Goodyear Turkey. ${ }^{130}$ The court found that the sales resulted from marketing coordination among the defendants, which supported the trial court's determination that shipment of the foreign manufacturers' tires into the state was “'a continuous and systematic' process rather than sporadic or episodic one.”131

In addition to finding sufficient contacts, the state appellate court considered whether exercise of jurisdiction was fair. ${ }^{132}$ It found that the plaintiffs had an interest in litigating in their home state ${ }^{133}$ and that North Carolina had an interest in providing a forum. ${ }^{134}$ It further recognized that while the exercise of jurisdiction imposed a burden on the foreign defendants, the defendants' close ties with domestic defendants reduced

contacts form part of the statement of plaintiff's claim in a well-pleaded complaint.

128. See Brown, 681 S.E.2d at 394 ("Defendants have... purposefully and intentionally manufactured tires and placed them in the stream of interstate commerce without any limitation on the extent to which those tires could be sold in North Carolina.”).

129. Id. at 393.

130. Id. at 393-94. The total numbers did not include tires attached to cars that were delivered into the state. Id. at 394.

131. See id. at 394-95 (“[T]he trial court's findings reflect that thousands of [Defendant's tires] were distributed in North Carolina as a result of a highly organized distribution process that involved Defendants and other Goodyear affiliates.”). Goodyear coordinated international sales and marketing by developing business plans and sales plans. Id. at 386 n.4. "After [determining specific market needs], the needed tires would be manufactured, shipped to the United States, and distributed to retailers and similar entities using Goodyear's existing distribution system.” Id.

132. See id. at 394-96.

133. See id. ("[R]equiring Plaintiffs, who have no ties to France, to litigate their claims in the French courts would impose a considerable burden on them.”).

134. See id. ("North Carolina has a well-recognized interest in providing a forum in which its citizens are able to seek redress for injuries that they have sustained ...."). 
this burden. ${ }^{135}$ In contrast, the plaintiffs would face a greater burden if the court refused to exercise jurisdiction. ${ }^{136}$

In affirming the lower court's decision, the appellate court specifically addressed the defendants' argument that stream of commerce does not support general jurisdiction. ${ }^{137}$ The court observed that delivery of a limited quantity of products might not support general jurisdiction. ${ }^{138}$ But the court found the opposite to be the case:

[T] hat is not the situation present here. Instead, the trial court's findings reflect that thousands of tires manufactured by each of the Defendants were distributed in North Carolina as the result of a highly organized distribution process that involved Defendants and other Goodyear affiliates. Thus, [there was] sufficient basis ... to support a finding of general personal jurisdiction ....

\section{B. Justice Ginsburg's Rejection of Hybrid Jurisdiction}

In reversing, Justice Ginsburg wrote a broad opinion for the unanimous Court to provide greater clarity for practitioners and lower courts. ${ }^{140}$ She insisted on the need to distinguish "general or all-purpose

135. See id. ("Although there is no question but that requiring Defendants to defend an action in [North Carolina] would be burdensome as well, that burden is alleviated to some extent by the fact that Defendants have corporate affiliates in the United States with business interests in North Carolina ....”). The trial court had found that the foreign defendants were not inconvenienced, in part, because they were represented by the same attorneys who were representing the U.S. corporations. Id. at 387.

136. See id. at 394 (“[A] greater burden would be imposed upon [the] Plaintiffs in the event that they [would have been] required to litigate their claims in France compared to the burden that would be imposed upon Defendants in the event that they [would have been] required to defend [in North Carolina].”).

137. Id. at 394-95.

138. Id.

139. Id. at 395.

140. The opinion decided much more than the question presented by the corporate defendants of " $[$ w] hether a foreign corporation is subject to general personal jurisdiction . . . merely because other entities distribute in the forum state products initially placed in the stream of commerce by the corporation.” Brief for Petitioners, supra note 117, at i. The Court refused the corporate defendants' invitation to base its decision on the narrow presence-in-the-forum requirement, which would turn on the presence of some property or authorized agent within the forum state. Id. at 14,21 . The Court also ignored the pre-International Shoe authority that the corporate defendants proposed as a narrow basis for the decision. Id. at 7, 23-24 (citing Consol. Textile v. Gregory, 289 U.S. 85, 88 (1933)). See Transcript of Oral Argument, supra note 17, at 5, 10-11 (“[I]n particular . . just as the Rosenberg case was binding in Helicopteros on the point that mere purchases are not enough for general jurisdiction, here, Consolidated Textile v. Gregory is binding on the flip side of that, which is that mere sales in the State are not enough for general jurisdiction.” (italics added)). 
jurisdiction” from "specific or case-linked jurisdiction," 141 excluding any intermediary class or hybrid category of jurisdiction. ${ }^{142}$ She sought to clarify the level of activity required for general personal jurisdiction: a state may exercise general personal jurisdiction over foreign corporations "when their affiliations with the State are so 'continuous and systematic' as to render them essentially at home in the forum State."143

Because the deaths in France resulted from conduct unrelated to North Carolina, the state could not exercise specific personal jurisdiction. ${ }^{144}$ The Court also found that the corporate activity was insufficient to support general personal jurisdiction:

Some of the tires made abroad by Goodyear's foreign subsidiaries ... . had reached North Carolina through "the stream of commerce"; that connection, the Court of Appeals believed, gave North Carolina courts the handle needed for the exercise of general jurisdiction over the foreign corporations.

A connection so limited between the forum and the foreign corporation... is an inadequate basis for the exercise of general jurisdiction. Such a connection does not establish the "continuous and systematic" affiliation necessary to empower North Carolina courts to entertain claims unrelated to the foreign corporation's contacts with the State. ${ }^{145}$

C. The Narrow Reading: Extending the Holding in Helicopteros from Purchases to Sporadic Sales

For a Court committed to a categorical differentiation between general and specific jurisdiction, Goodyear Dunlop Tires presented an easy case. Some corporate activity, even if continuous and located

141. Goodyear Dunlop Tires, 131 S. Ct. at 2851 (citing Helicopteros Nacionales de Colom., S.A. v. Hall, 466 U.S. 408, 414 nn.8-9 (1984)).

142. Justice Brennan favored a form of hybrid jurisdictional analysis in his Helicopteros dissent. See Helicopteros, 466 U.S. at 427-28 (Brennan, J., dissenting).

143. Goodyear Dunlop Tires, 131 S. Ct. at 2851 (quoting Int'l Shoe Co. v. Washington, 326 U.S. 310, 317 (1945)). In contrast to general jurisdiction, the Court asserted that a state may exercise specific jurisdiction based "on an 'affiliatio[n] between the forum and the underlying controversy,' principally, [an] activity or an occurrence that takes place in the forum State and is therefore subject to the State's regulation.” Id. (first alteration in original) (quoting von Mehren \& Trautman, supra note 3 , at 1136 ).

144. Id. The state appellate court acknowledged the lack of specific jurisdiction. See supra notes $126-27$.

145. Id. (citation omitted) (citing Brown v. Meter, 681 S.E.2d 382, 394-95 (N.C. Ct. App. 2009), rev'd sub nom. Goodyear Dunlop Tires Operations, S.A. v. Brown, 131 S. Ct. 2846 (2011)). 
within a state, does not support personal jurisdiction over claims unrelated to the activity. ${ }^{146}$ Justice Ginsburg consulted the Court's two general jurisdiction decisions after International Shoe for guidance. ${ }^{147}$

She characterized the defendant's activity in Perkins as tantamount to establishing a purely in-state business in Ohio. ${ }^{148}$ She quoted with approval the Court's prior characterization that "Ohio was the corporation's principal, if temporary, place of business." "Although a business centered in the forum state provided the paradigm for general jurisdiction, ${ }^{150}$ Justice Ginsburg did not limit general jurisdiction to a corporation's place of incorporation or principal place of business. Instead, she relied on the holding in Helicopteros that a regular course of purchases were insufficient to support general jurisdiction and announced: "We see no reason to differentiate from the ties to Texas held insufficient in Helicopteros, the sales of petitioners' tires sporadically made in North Carolina through intermediaries." ${ }^{151}$ To the Court, the sales in Goodyear Dunlop Tires failed to establish systematic and continuous contacts. The foreign affiliates were "in no sense at home in North Carolina. Their attenuated connections to the State fall far short of ... 'the continuous and systematic general business contacts' necessary to empower North Carolina to entertain suit against them on claims unrelated to anything that connects them to the State.”152

146. Id. at 2856. “A corporation's 'continuous activity of some sorts within a state,' International Shoe instructed, 'is not enough to support the demand that the corporation be amenable to suits unrelated to that activity." 'Id. (quoting Int'l Shoe, 326 U.S. at 318).

147. See generally id. at 2856-57 (discussing the Perkins and Helicopteros decisions)

148. See id. at 2856 ("To the extent that the company was conducting any business during and immediately after the Japanese occupation of the Philippines, it was doing so in Ohio: the corporation's president maintained his office there, kept the company files in that office, and supervised from the Ohio office 'the necessarily limited wartime activities of the company."' (quoting Perkins v. Benguet Consol. Mining Co., 342 U.S. 437, 447-48 (1952))).

149. Id. (quoting Keeton v. Hustler Magazine, Inc., 465 U.S. 770, 779-80 n.11) (internal quotation marks omitted).

150. The Court referred to Perkins as "[t]he textbook case of general jurisdiction." Id. (alteration in original) (quoting Donahue v. Far E. Air Transp. Corp., 652 F.2d 1032, 1037 (D.C. Cir. 1981)) (internal quotation marks omitted).

151. Id. The Court's reference to intermediaries is important to the narrow framing of its decision, but the record is unclear. Counsel for the plaintiffs contended that the foreign manufacturers completed direct shipments of products from the factory to buyers that Goodyear USA had identified in North Carolina. Transcript of Oral Argument, supra note 17, at 36-37. Plaintiffs' counsel relied on the web of connections between the corporations to establish sufficient contacts. See id. at 36-37, 39-40 (describing Goodyear USA's various distribution schemes and arguing that the forum should have general jurisdiction over such a "tightly controlled system").

152. Goodyear Dunlop Tires, 131 S. Ct. at 2857 (citations omitted) (quoting Helicopteros Nacionales de Colom., S.A. v. Hall, 466 U.S. 408, 416 (1984)). 


\section{Characterizing the Facts}

The opinion's characterization of the facts supports a narrow reading of the opinion. To find that the record established no more than "sales... sporadically made in [state] through intermediaries," 153 the Court minimized the volume of the defendants' in-state sales by comparing them to the higher volume of sales elsewhere. ${ }^{154}$ Justice Ginsburg also minimized the foreign defendants' regular dealings with Goodyear USA and emphasized the role of intermediaries. ${ }^{155}$

The finding of sporadic sales ${ }^{156}$ flows from an observation that a relatively small proportion of the international manufacturers' products appear in the forum market. ${ }^{157}$ As the Court observed:

They have no place of business, employees, or bank accounts in North Carolina. They do not design, manufacture, or advertise their products in North Carolina. And they do not solicit business in North Carolina or themselves sell or ship tires to North Carolina customers. Even so, a small percentage of [defendants'] tires (tens of thousands out of tens of millions manufactured between 2004 and 2007) were distributed within North Carolina by other Goodyear USA affiliates. ${ }^{158}$

To minimize the regularity of the distribution, the opinion added that the imported tires were custom-ordered for special purposes ${ }^{159}$ and did not include the type of tire that allegedly caused the deaths in France. ${ }^{160}$

The opinion omits details about the volume of sales and does not address the economic significance of the North Carolina sales to the overall business of the foreign manufacturers. Instead, it declares the

153. Id. at 2856.

154. See id. at 2852 (finding that "a small percentage of [defendants'] tires ... were distributed within North Carolina" and noting that the defendants "manufacture tires primarily for sale in European and Asian markets”).

155. Id. at 2856-57. The plaintiffs insisted that the record did not support this, and they argued that shipments were made directly to purchasers identified by Goodyear USA and directly to Goodyear USA in North Carolina. Transcript of Oral Argument, supra note 17, at 36-37; see also supra note 130 and accompanying text (calculating the total volume of tires shipped from defendants to Goodyear USA from 2004 to 2007).

156. Goodyear Dunlop Tires, 131 S. Ct. at 2856.

157. See id. at 2852.

158. Id.

159. Id.

160. Id.; see also Transcript of Oral Argument, supra note 17, at 30-31 ("The Goodyear Regional RHS tire ... was not generally designed for the U.S. market, although it was brought [to the United States] under special circumstances.”). 
volume small by comparison. ${ }^{161}$ This comparative evaluation of business contacts for purposes of general jurisdiction parallels the Court's treatment of contacts for purposes of legislative jurisdiction, ${ }^{162}$ but it departs from the analysis proposed by leading scholars whose work the opinion cites elsewhere with approval. ${ }^{163}$ The comparative approach reaches an appropriate result in situations where fundamental unfairness counsels against subjecting a foreign corporation to either adjudicatory or legislative jurisdiction. But the approach's conclusion that the volume of sales is insufficient makes it unclear whether the same volume of sales would suffice if the foreign corporation engaged in less extensive international business. ${ }^{164}$

161. Goodyear Dunlop Tires, 131 S. Ct. at 2852.

162. Phillips Petroleum Co. v. Shutts, 472 U.S. 797, 814-15, 819, 823 (1985) (holding that due process prohibited application of Kansas interest rate to substantive claims where "over $99 \%$ of gas leases and some 97\% of plaintiffs" had "no apparent connection to the State of Kansas" notwithstanding the presence of hundreds of Kansas plaintiffs in the class and property in-state related to claims).

163. The Court cites the work of Brilmayer and her coauthors multiple times in its opinion. See, e.g., Goodyear Dunlop Tires, 131 S. Ct. at 2851, 2854 (citing Brilmayer et al., supra note 12, at 728, 782). But in the work cited, Brilmayer and her coauthors write:

We should not treat defendants as less amenable to suit merely because they carry on more substantial business in other states .... Thus, the due process clause should permit general jurisdiction on the basis of activities when the defendant reaches the quantum of local activity in which a purely local company typically would engage.

Brilmayer et al., supra note 12, at 742. Another scholar has proposed that "requisite minimum contacts supporting general jurisdiction exist when the nonresident defendant is engaging in continuous activities in the forum similar in nature and volume to the in-state activities of an enterprise domiciled or based in the forum." Charles W. "Rocky" Rhodes, Clarifying General Jurisdiction, 34 SETON HALL L. REV. 807, 811 (2004). To prevent any misunderstanding, Brilmayer and her coauthors emphasize that, "for purposes of general jurisdiction, the relevant issue is the absolute amount of activity, not the amount of activity relative to what the defendant does outside the state.” Brilmayer et al., supra note 12, at 743. In contrast, they also propose that a court should evaluate a nonresident defendant's contacts based on property by comparing them to the proportion of the defendant's total assets. Id. at 770-71.

While focusing on the local quantum of activity, Brilmayer and her coauthors insist on the need to differentiate interstate and in-state activity. Id. at 743-48. Because of the burden placed on interstate commerce by the exercise of adjudicatory jurisdiction, id. at 745-46, they propose that "courts should weigh a defendant's intrastate contacts more heavily and should discount purely interstate activity in determining whether to exercise general jurisdiction." Id. at 747. "Exercising ... jurisdiction [based on a defendant's sporadic sales in the forum state] ignores the discriminatory and burdensome impact on interstate trade that results when interstate contacts are the sole basis for general jurisdiction.” See id. at 748 (citing Quaker Oats Co. v. Chelsea Indus., Inc., 496 F. Supp. 85, 88 (N.D. Ill. 1980)). Based on this analysis, the holding in Goodyear Dunlop Tires might be correct because of the wholly interstate character of the foreign affiliates' contacts, but not because the foreign affiliates had insufficient local contacts compared to their far greater level of activity out of state.

164. For example, a Turkish corporation might engage exclusively in one activitymanufacturing custom tires for the North Carolina market. It would be hard to characterize 


\section{Rejecting Forum State Interests in Evaluating the Sufficiency of Contacts for General Jurisdiction}

The Court's attention to the proportion of sales rather than their total volume may conceal an implicit concern with the fairness of the forum. Nevertheless, the Court's opinion makes clear that neither considerations of fairness to the parties nor the strength of the forum state's interest supports a finding of general jurisdiction in the absence of continuous and systematic activity by the defendant. ${ }^{165}$ The Court briefly comments in a footnote that both a plaintiff's relationship to a forum and the forum state's interest based on the residence of the plaintiff are entirely irrelevant for purposes of evaluating general jurisdiction. ${ }^{166}$

The effect of the Court's rejection of the plaintiffs' and forum state's interests on the analysis of general jurisdiction remains uncertain because the opinion does not set forth the overall analysis required for a finding of general jurisdiction. ${ }^{167}$ At a minimum, the Court appears committed

thousands of annual sales by such a corporation as "sporadic," even though the volume of sales might not rise to the level of Goodyear Turkey's sales of tires distributed in North Carolina. There are good reasons for permitting general jurisdiction over the hypothetical Turkish corporation. See ROBERT A. LEFLAR ET AL., AMERICAN CONFLICTS LAW 52 (4th ed. 1986) (arguing that general jurisdiction should be permitted over a corporation that conducts "substantial activities over a period of time" in a particular state). But the "comparative volume of sales" discussion in Goodyear Dunlop Tires leaves open the question of whether North Carolina would have jurisdiction over the hypothetical company, and the opinion contains dictum that suggests jurisdiction would not exist. See infra Part IV.E.1.

165. Justice Ginsburg acknowledges that, "[a]s further support, the court invoked North Carolina's 'interest in providing a forum in which its citizens are able to seek redress for [their] injuries,' and noted the hardship North Carolina plaintiffs would experience '[were they] required to litigate their claims in France."” Goodyear Dunlop Tires, 131 S. Ct. at 2853 (alterations in original). The Court's discussion implies that the state court had employed fairness factors to support its finding of sufficient contacts. On the contrary, the state court found contacts based on the defendants' continuous and systematic sales and then considered the burden on the plaintiff, the burden on the defendant, and the state interest in providing a forum. See supra notes 131-36 and accompanying text.

The Court's opinion did not consider the actual burden on the defendant. This is in keeping with the Court's holdings that lack of inconvenience does not support personal jurisdiction in the absence of a constitutionally sufficient relationship between the defendant and the forum. See, e.g., Hanson v. Denckla, 357 U.S. 235, 251 (1958) ("However minimal the burden of defending in a foreign tribunal, a defendant may not be called upon to do so unless he has had the "minimal contacts’ with that State . . .” (citing Int'l Shoe Co. v. Washington, 326 U.S. 310, 319 (1945))).

166. Goodyear Dunlop Tires, 131 S. Ct. at 2857 n.5 (“[G]eneral jurisdiction to adjudicate has in [United States] practice never been based on the plaintiff's relationship to the forum.” (second alteration in original) (quoting von Mehren \& Trautman, supra note 3, at 1137) (internal quotation marks omitted)).

167. The Court may have avoided doing so because it was unnecessary to its decision or because there was no agreement as to the proper analysis for general jurisdiction. See infra notes 228-37 and accompanying text. 
to the position, announced in previous decisions, that the absence of any burden on the defendant will not permit general jurisdiction without sufficient contacts between the defendant and the forum state. ${ }^{168}$ Justice Ginsburg seems, however, to assert more forcefully that the sufficiency of contacts for purposes of general jurisdiction is an independent inquiry and that neither the plaintiff's interests nor the forum's interests may discount the required level of activity. ${ }^{169}$ In other words, Justice Ginsburg appears to reject, at least for general jurisdiction, Justice Brennan's view that the interests of the plaintiff and forum state "sometimes serve to establish the reasonableness of jurisdiction upon a lesser showing of minimum contacts than would otherwise be required." 170

\section{Disregarding Business Affiliations Short of a Common Enterprise}

Where the North Carolina courts found systematic coordination of marketing, manufacturing, and distribution among the foreign corporations and Goodyear USA, ${ }^{171}$ the Court's opinion characterizes the

168. See, e.g., World-Wide Volkswagen Corp. v. Woodson, 444 U.S. 286, 294 (1980).

[T] he Due Process Clause "does not contemplate that a state may make binding a judgment in personam against an individual or corporate defendant with which the state has no contacts, ties, or relations." Even if the defendant would suffer minimal or no inconvenience from being forced to litigate before the tribunals of another State; even if the forum State has a strong interest in applying its law to the controversy; even if the forum State is the most convenient location for litigation, the Due Process Clause, acting as an instrument of interstate federalism, may sometimes act to divest the State of its power to render a valid judgment.

Id. (citations omitted) (quoting Int'l Shoe, 326 U.S. at 319) (citing Hanson, 357 U.S. at 251).

169. Justice Ginsburg expressly limited the rejection of fairness considerations to general jurisdiction and contrasted this to their role in determining specific personal jurisdiction. Goodyear Dunlop Tires, 131 S. Ct. at 2857 n.5 ("When a defendant's act outside the forum causes injury in the forum, by contrast, a plaintiff's residence in the forum may strengthen the case for the exercise of specific jurisdiction.” (citing Calder v. Jones, 465 U.S. 783, 788 (1984); von Mehren \& Troutman, supra note 3 , at 1137)).

It remains uncertain, however, whether Justice Ginsburg views the fairness of exercising personal jurisdiction as a consideration that reduces the requirement for other contacts or whether she views it as an independent consideration that may strengthen the case for specific jurisdiction after constitutional minimal contacts have been established.

170. Burger King Corp. v. Rudzewicz, 471 U.S. 462, 477 (1985) (citing Keeton v. Hustler Magazine, Inc., 465 U.S. 770, 780 (1984); Calder, 465 U.S. at 788-89; McGee v. Int'l Life Ins. Co., 355 U.S. 220, 223-24 (1957)).

171. Brown v. Meter, 681 S.E.2d 382, 386 n.4, 394 (N.C. Ct. App. 2009), rev'd sub nom. Goodyear Dunlop Tires Operations, S.A. v. Brown, 131 S. Ct. 2846 (2011). The North Carolina appellate court found that the tires reached the state as a consequence of a "highly-organized distribution process.” Id. at 394. 
facts as showing only that "some" tires manufactured abroad by subsidiaries of Goodyear USA reached the forum state. ${ }^{172}$ The opinion emphasizes both the foreign manufacturers' behavior that occurred outside the United States ${ }^{173}$ and their lack of property, agents, and sales activity in state. ${ }^{174}$

The Court omits any discussion of the web of corporate relationships that resulted in the daily delivery of thousands of tires into North Carolina. ${ }^{175}$ This and its failure to discuss the actual relations among the Goodyear affiliates prevent a clear understanding of how broadly the holding applies. In dictum, the opinion suggests the possibility that the state court might exercise general jurisdiction over foreign manufacturers that form part of a "single enterprise" with other entities over which the

172. See Goodyear Dunlop Tires, 131 S. Ct. at 2851 (citing Meter, 681 S.E.2d at 394-95) (describing tens of thousands of tires as "[s]ome" tires). The state appellate court's opinion nowhere established that the foreign affiliates were subsidiaries, while Justice Ginsburg, who elsewhere refers to them as "indirect subsidiaries," id. at 2852, neither explains the corporate relationship between the defendants nor identifies the place in the record that indicates the relationship. The descriptive label may derive from the petitioners' corporate disclosure statement. See Brief for Petitioners, supra note 117, at iii (listing defendants as "indirect subsidiaries" in the corporate disclosure statement).

The state appellate court focused on the coordination of marketing and manufacturing through which Goodyear USA communicated product needs to foreign affiliates who then manufactured the products for distribution through Goodyear USA in North Carolina and other markets. See Meter, 681 S.E.2d at 393-94 (finding that the manufacture and distribution of the tires into interstate commerce, not excluding North Carolina, was sufficient to establish general jurisdiction).

173. See Goodyear Dunlop Tires, 131 S. Ct. at 2852 (noting that the foreign affiliates "manufacture tires primarily for sale in European and Asian markets," which "differ in size and construction from tires ordinarily sold in the United States"). The opinion supports the inference, however, that the United States was a secondary market for special order tires for heavier vehicles. See id. (noting that most tires distributed in North Carolina were "custom ordered to equip specialized vehicles").

174. Id. (discussing the problematic claim that defendants neither sold in state nor "themselves" shipped tires into the state); see supra note 151 . Justice Ginsburg's rhetoric disengages the defendants from active agency in the forum. See Goodyear Dunlop Tires, 131 S. Ct. at 2852 (“[Defendants'] tires ... were distributed ... by ... affiliates.”). The paragraph discussing the facts supporting personal jurisdiction consists of three sentences describing activity in which the foreign affiliates have not engaged. $I d$. These are followed by two sentences in the passive voice explaining that the tires "were distributed" and "were ... custom ordered." Id.

175. Instead, the Court dismissed the "belatedly assert[ed]... 'single enterprise' theory" argument urged by the plaintiffs. Goodyear Dunlop Tires, 131 S. Ct. at 2857 (noting that because the theory was not addressed in the plaintiffs' brief, the Court would "not address it"). Justice Scalia suggested during argument that an opinion that failed to address jurisdiction based on enterprise liability would be of limited use to the bar:

We haven't resolved a whole lot if we leave that question [of enterprise liability] open, have we? You want us to write an opinion that says unless you-unless you ignore the separate corporate existence of the subsidiary-(a question on which we express no opinion) there can be no jurisdiction in cases like this? Is that the kind of an opinion that the world is waiting for?

Transcript of Oral Argument, supra note 17, at 8. 
state court could exercise general jurisdiction. ${ }^{176}$ To show such a single enterprise, the Court suggests, would require piercing Goodyear's corporate veil for jurisdictional purposes, ${ }^{177}$ but the posture of the case prevented the Court from reaching the issue. ${ }^{178}$

The Court's treatment of the single enterprise theory offers future plaintiffs one possible strategy for establishing general jurisdiction while simultaneously signaling that it will be difficult to establish jurisdiction under such a theory. The Court assumes, if only for the sake of argument, that the total contacts of the corporations with North Carolina would suffice to create general jurisdiction if a court attributed the activity to a single corporation. ${ }^{179}$ But the Court's insistence that the corporate contacts be evaluated separately makes clear that due process requires states to respect the separate existence of foreign corporations in the absence of circumstances that warrant piercing the corporate veil. ${ }^{180}$

The opinion leaves no doubt that indirect sporadic sales through intermediaries, by themselves, never establish general jurisdiction. ${ }^{181}$ It does not explain what additional relationships-if any-among the business entities responsible for the manufacturing and sale of products in a state would suffice.

176. The Court cited an article describing the requirements for "merging [a] parent and subsidiary for jurisdictional purposes.” Goodyear Dunlop Tires, 131 S. Ct. at 2857 (citing Lea Brilmayer \& Kathleen Paisley, Personal Jurisdiction and Substantive Legal Relations: Corporations, Conspiracies, and Agency, 74 CALIF. L. REv. 1, 14, $29-30$ (1986)). Even the North Carolina Court of Appeals, however, considered the defendants to be "separate corporate entities ... not directly responsible for the presence in North Carolina of tires that they had manufactured." Brown, 681 S.E.2d at 392.

177. Goodyear Dunlop Tires, 131 S. Ct. at 2857 (citing Brilmayer \& Paisley, supra note 176, at 14, 29-30).

178. The Court refused to reach the issue because plaintiffs had not raised it at trial, on appeal, or in their brief to the Court. Id.

179. It is not certain that the total contacts would establish that the single enterprise is "at home" in the state. See infra Part IV.D.3.

180. The Court's discussion was limited to enterprise liability on piercing the corporate veil. See Goodyear Dunlop Tires, 131 S. Ct. at 2857. It did not separately consider an alternative theory under which corporations, while retaining their distinct legal identity, may form a joint venture that results in the attribution of one corporation's acts to the other for purposes of both liability and jurisdiction. Cf. UNIFORM P'SHIP ACT of 1997 §§ 101(10), 202(a), 5 U.L.A. 61, 92 (2001) (providing that partnerships arise when persons, including corporations, carry on as co-owners a business for profit).

181. Goodyear Dunlop Tires, 131 S. Ct. at 2856. 


\section{Limiting the Holding to Corporations}

In other cases, some members of the Court have expressed doubt about whether state courts may exercise general jurisdiction over an individual based on a high level of contacts. ${ }^{182}$ The opinion in Goodyear Dunlop Tires offers no clues as to the Court's current view. The opinion addresses activity that subjects corporations to general jurisdiction but has no direct application to individuals. Thus, it sheds no light on the question of whether state courts may exercise general jurisdiction over individuals who engage in systematic and continuous business activity in a state. ${ }^{183}$

Justice Ginsburg traces "continuous and systematic contacts" to decisions involving corporate activity. ${ }^{184}$ She does not, however, explain whether such contacts establish the means for determining the corporation's principal place of business, furnish an alternative basis for jurisdiction when corporations engage in sufficient activity, or establish an independent threshold for "minimum contacts" that applies equally to corporations and individuals.

\section{The Broad Reading: Restricting General Jurisdiction over Corporations to States of Incorporation and Principal Places of Business}

Although the opinion's characterization of the record supports a narrow reading that disallows general jurisdiction based on sporadic sales through intermediaries, the opinion itself provides grounds for a far broader reading. Under this broader reading, the Court disfavors general jurisdiction over corporations and restricts such jurisdiction to those

182. Four members of the Court have questioned whether a court may exercise such "'contacts'based [general] jurisdiction" over individuals but declined to express a view on the matter. See Burnham v. Superior Court, 495 U.S. 604, 610 n.1 (1990) (plurality opinion).

183. As a practical matter, contacts-based general jurisdiction will only be necessary for an individual who is neither domiciled in a state nor physically present so as to be amenable to personal service. Cf. id. at 627-28 (holding that a state may exercise general jurisdiction over nonresident defendant personally served in the state); Milliken v. Meyer, 311 U.S. 457, 464 (1940) (holding that a state may exercise general jurisdiction over a person domiciled in the state).

184. Goodyear Dunlop Tires, 131 S. Ct. at 2853 (discussing International Shoe and Helicopteros). The opinion notes that "[f]or an individual, the paradigm forum for the exercise of general jurisdiction is the individual's domicile." The opinion then describes the paradigm forum for general jurisdiction by analogy to the individual's domicile, noting that "it is an equivalent place, one in which the corporation is fairly regarded as at home.” Id. at 2853-54 (citing Brilmayer et al., supra note 12, at 728). 
states in which corporations were traditionally subject to general jurisdiction-the state of incorporation and the principal place of business. $^{185}$

1. Extending the Opinion Beyond Corporations from a Foreign Country

The Court frames the issue: "Are foreign subsidiaries of a United States parent corporation amenable to suit in state court on claims unrelated to any activity of the subsidiaries in the forum State?"186 But the opinion makes clear that the holding is not limited to corporation from foreign countries. ${ }^{187}$ None of the Court's reasoning invokes the special status of the defendants as existing under the laws of foreign countries as opposed to sister states. ${ }^{188}$ And the Court's own references to "foreign corporations" include all non-domestic corporations. ${ }^{189}$ The foreign manufacturers could not constitutionally face general jurisdiction in North Carolina because they were not "at home" in North Carolina due to a lack of continuous and systematic business contacts; their international legal status did not affect the analysis. ${ }^{190}$

\section{Disfavoring General Jurisdiction over Corporations}

The Court's exclusive classification of cases into specific and general jurisdiction is consistent with prior decisions. ${ }^{191}$ The Court breaks new ground, however, with the announcement that the continuous and systematic affiliations required for general jurisdiction must be tantamount to establishing a legal home. ${ }^{192}$

185. The broadest possible reading approaches the position advocated for in the Brief of the Chamber of Commerce of the United States of America as Amicus Curiae in Support of Petitioners at 3-4, Goodyear Luxembourg Tires, 131 S. Ct. 2846 (No. 10-76) (arguing that general jurisdiction over a corporation is limited to place of incorporation and place of "systematic supervision of corporate activities," which is comparable to the level of the defendant's in-state activity in Perkins).

186. Goodyear Dunlop Tires, 131 S. Ct. at 2850.

187. Id. at 2851 ("A court may assert general jurisdiction over foreign (sister-state or foreigncountry) corporations .....”).

188. See id. at 2856-57.

189. See id. at 2851.

190. See id. at 2857.

191. See supra Part II.B; see also Goodyear Dunlop Tires, 131 S. Ct. at 2853 (observing that International Shoe and Helicopteros recognized categories of specific and general jurisdiction).

192. Goodyear Dunlop Tires, 131 S. Ct. at 2851. The continuous and systematic affiliations must "render them essentially at home in the forum State." Id. (citing Int'l Shoe Co. v. Washington, 326 U.S. 310, 317 (1945)). International Shoe does not employ the phrase "at home." For a discussion on how to define "at home," see infra note 196 and accompanying text. 
The restriction of general jurisdiction over a corporation to a place where it is "at home" is troubling. A court could traditionally exercise general jurisdiction over individuals based on multiple groundsdomicile or habitual residence, presence, or consent. ${ }^{193}$ Justice Ginsburg privileges domicile as the archetypal form of general jurisdiction over an individual by proposing that a state in which a corporation is "at home" should similarly have authority to exercise general jurisdiction over the entity. ${ }^{194}$ Jurisdiction based on domicile is an established historical practice, yet reasons supporting the practice remain obscure. ${ }^{195}$

The phrase "at home" is a neologism lacking any fixed legal meaning. ${ }^{196}$ While an individual may feel "at home” in many places, natural persons have traditionally had one and only one legal hometheir domicile. ${ }^{197}$ For individuals, the law assigns this legal home at

193. Von Mehren \& Trautman, supra note 3, at 1137. 728).

194. Goodyear Dunlop Tires, 131 S. Ct. at 2853-54 (citing Brilmayer et al., supra note 12, at

195. Von Mehren and Trautman contended that general jurisdiction based on the individual's domicile arose from the need for one "certain and predictable place" for litigation. Von Mehren and Trautman, supra note 3, at 1137. This is not entirely convincing. The authors neither explained why certainty should provide an adequate basis for jurisdiction nor considered the fact that a person's domicile can be uncertain.

In contrast, Brilmayer and her coauthors sought to justify domicile-based jurisdiction by grounding it in the power of domiciliaries to influence forum law and by their receipt of reciprocal benefits. Brilmayer et al., supra note 12, at 733. This explanation fails, however, to explain why defendants are subject to general jurisdiction where they cannot vote. Rhodes similarly argues that the "reciprocal benefits or exchange theory" best explains general jurisdiction based on domicile. See Rhodes, supra note 163, at 911, 913.

Instrumental explanations that justify the burden of jurisdiction by reference to the benefits a corporation receives from the state of incorporation or principal place of business are subject to Justice Scalia's critique of instrumental justifications for general jurisdiction based on personal service. See Burnham v. Superior Court, 495 U.S. 604, 623 (1990) (plurality opinion) (observing that benefits a transient visitor experiences in the forum state seem inadequate to make it fair for the state to enter an enforceable judgment disposing of all of the defendant's assets).

196. Counsel for petitioners apparently first injected the "at home" formula into the case. See Goodyear Dunlop Tires, 131 S. Ct. at 2853-54. While Chief Justice Stone assumed that general jurisdiction would be proper at a corporation's "home" in International Shoe, he placed his first use of the term in ironic quotation marks. Int'l Shoe, 326 U.S. at 317; see supra note 52 and accompanying text. It is unclear whether he meant the term as a loose synonym for principal place of business. See Int'l Shoe, 326 U.S. at 317 (using both the terms "home" and "principal place of business"). Justice Stone contrasted physical presence in the state, which establishes jurisdiction, with casual presence or single isolated activities unconnected with the claims and performed by an agent in a place other than where the corporation has its "home or other jurisdiction where it carries on more substantial activities." Id.

197. Domicile is a Latin cognate of "home." Definitions for domicile in turn sometimes invoke references to "home" or place of abode. See, e.g., RESTATEMENT (SECOND) OF CONFLICT OF LAWS $\S 11$ (1971) (“Domicil is a place, usually a person’s home ....”). 
birth $^{198}$ and recognizes it unless and until an individual establishes a new domicile. $^{199}$

A corporation's domicile is more uncertain. Although some archaic authorities defined a corporation's domicile as its place of incorporation, ${ }^{200}$ more recent authorities reject the terminology of domicile in relationship to corporations. ${ }^{201}$ There are good reasons why courts and legal authorities avoid assigning domicile or legal homes to corporations. The traditional tests for domicile focus on presence and subjective intent and do not apply to corporations. Moreover, for most purposes, the law recognizes that a corporation may have significant legal relationships with more than one state.

Justice Ginsburg leaves little doubt that cases in which the Court relaxed constitutional limits on specific personal jurisdiction must not be read to indicate a similar commitment to relaxing limits on general jurisdiction. $^{202}$ On the contrary, sharply distinguishing specific and general jurisdiction, she criticizes the North Carolina courts for confusing acts relevant for specific jurisdiction and those necessary for general jurisdiction. ${ }^{203}$ Justice Ginsburg looks to only three cases for understanding due process limits on general jurisdiction. She characterizes International Shoe as limiting general jurisdiction to a corporation's home, ${ }^{204}$ reads Perkins as analogizing the term "home" to a corporation's principal place of business, ${ }^{205}$ and construes Helicopteros

198. Id. § 14

199. The test for establishing domicile is physical presence coupled with the intent to remain indefinitely. Id. § 15-16, 18.

200. RESTATEMENT OF CONFLICT OF LAWS $§ 41$ (1934) (“A corporation is domiciled in the state where it was incorporated, and cannot acquire a domicil outside that state.”). The Restatement cited no authority for this doctrine, and its attempt to ascribe domicile to a corporation reflected the theoretical goal of ascribing a fixed state identity to corporations for the purpose of applying various choice-of-law rules that depended on domicile. See id.; see also JosePh H. BEALE, A TrEATISE ON THE CONFLICT OF LAWS $\S 41.1$ (1935). The principal author of the Restatement acknowledged criticism of the idea of corporate domicile; he defended it, without citing any authority, as a doctrine that provided convenience in applying the formal conflicts rules. BEALE, supra, § 41.1.

201. See, e.g., RESTATEMENT (SECOND) OF CONFLICT OF LAWS $\S 11$ (restricting domicile to natural persons). Though there is scant authority for the notion of corporate domicile, at least one statute refers to it. See 36 U.S.C. § 30901(b) (2006) (fixing the domicile of the Boy Scouts of America Corporation in the District of Columbia).

202. Goodyear Dunlop Tire Operations, S.A. v. Brown, 131 S. Ct. 2846, 2855 (2011).

203. See id. ("The North Carolina court's stream-of-commerce analysis elided the essential difference between case-specific and all-purpose (general) jurisdiction.”)

204. Id. at 2851 (citing Int'l Shoe Co. v. Washington, 326 U.S. 310, 317 (1945)).

205. Id. at 2857 (comparing defendants to those in Perkins and finding that they "are in no sense at home in North Carolina”). 
as refusing to extend general jurisdiction to a corporation that engages in "mere purchases" and training of employees in the forum state. ${ }^{206}$

3. Reducing General Jurisdiction to Place of Incorporation and Principal Place of Business

The Court's opinion identifies two places where a corporation will be "at home" and, thus, subject to general jurisdiction: the place of incorporation and the principal place of business. ${ }^{207}$ The opinion does not expressly prohibit other states from exercising general jurisdiction. In discussing caselaw, however, Justice Ginsburg emphasizes that in the only case in which continuous and systematic contacts permitted a finding of general jurisdiction, the corporation maintained its principal place of business in the forum state. ${ }^{208}$ Moreover, her opinion's rhetorical restriction of general jurisdiction to a corporation's home suggests that "continuous and systematic" corporate activity must be comparable to a principal place of business. ${ }^{209}$

Restricting unlimited general jurisdiction to a corporation's place of incorporation or principal place of business implements reforms proposed by legal scholars cited by Justice Ginsburg, ${ }^{210}$ but it stands in

206. Id. at 2856 (quoting Helicopteros Nacionales de Colom., S.A. v. Hall, 466 U.S. 408, 418 (1984) (internal quotation marks omitted).

207. Id. at 2853-54 (citing Brilmayer et al., supra note 12, at 728).

208. Id. at 2856 (citing Perkins v. Benguet Consol. Mining Co., 342 U.S. 437, 447-48 (1952)); see supra notes 102-03 and 149 and accompanying text. In fact, the corporate defendant may have resumed mining operations in the Philippines by the time the plaintiff commenced the action in Ohio. See von Mehren \& Trautman, supra note 3, at 1144.

209. See Goodyear Dunlop Tires, 131 S. Ct. at 2856-57 (noting that in Perkins, the corporation had its de facto principal place of business in the forum state and that the defendants in Goodyear Dunlop Tires were, unlike the defendant in Perkins, not at home). Four Justices are not eager to permit general jurisdiction outside the corporation's place of incorporation and principal place of business. J. McIntyre Mach., Ltd. v. Nicastro, 131 S. Ct. 2780, 2787 (2011) (plurality opinion) ("Citizenship or domicile—or, by analogy, incorporation or principal place of business for corporations-also indicates general submission to a State's powers.” (citing Goodyear Dunlop Tires, 131 S. Ct. at 2854)).

210. Brilmayer and her coauthors advocated general jurisdiction based only on "unique affiliations," like place of incorporation and principal place of business. Brilmayer et al., supra note 12, at 735. Other scholars have opined that "absent the kind of total, close, and continuing relations to a community implied in incorporation or in the location of a head office within a state, jurisdiction over legal persons ... should take the form of specific jurisdiction.” See von Mehren \& Trautman, supra note 3, at 1139-44. Von Mehren and Trautman inaccurately predicted the decline of other forms of general jurisdiction and anticipated the Court's decision when they characterized Perkins as "approving the forum utilized as a surrogate for the place of incorporation or head office." Id. at 1144. Twitchell proposed restricting general jurisdiction to the corporation's "home base," which she defined for corporations as the state where they are headquartered, but also argued that courts 
tension with the analysis proposed by other scholars whom she also cites with approval. ${ }^{211}$ For Brilmayer and her coauthors, the essential difference between general and specific jurisdiction lies in the number of contacts. $^{212}$ These authors propose that a corporation may be subject to general personal jurisdiction in three different types of forums-the place of incorporation, the principal place of business, and a place where the corporation has a sufficient "absolute quantum of activity.",213 Accordingly, the authors argue that multiple additional states could exercise general jurisdiction over a defendant that carried on continuous and systematic activities in those states. ${ }^{214}$

Justice Ginsburg's opinion provides no detailed explanation for why the facts did not amount to the continuous and systematic activity required for general jurisdiction. ${ }^{215}$ On the one hand, it emphasizes that the quantity of sales and efforts to serve a market in a forum-facts relevant for specific jurisdiction-do not constitute continuous and

should recognize jurisdiction in the state of incorporation. Twitchell, supra note 103, at 669-70.

211. See Goodyear Dunlop Tires, 131 S. Ct. at 2851, 2853-54.

212. Brilmayer and her coauthors explain:

What difference does it make whether we characterize assertion of state judicial power as specific or general? Differentiating between the two is crucial for one important reason: fewer contacts-perhaps only one-will support specific jurisdiction. In contrast, the Supreme Court's opinions in Perkins and Helicopteros suggest that assertions of general jurisdiction require a larger number of contacts.

Brilmayer et al., supra note 12, at 727 (footnotes omitted) (citing Helicopteros Nacionales de Colom., S.A. v. Hall, 466 U.S. 408, 415-16 (1984); McGee v. Int'l Life Ins. Co., 355 U.S. 220, 223 (1957); Perkins, 342 U.S. at 447).

213. Id. at 734. Brilmayer and her coauthors observe that states may define the principal place of business differently, but the authors do not explain why a state's definition should affect the due process limits on the state's exercise of judicial power. Id. at 734-35.

214. See id. at 734-35 (acknowledging the "other bases, such as activities, presence, property, and consent" have been used to establish general jurisdiction).

For Brilmayer and her coauthors, additional states could exercise general jurisdiction but not necessarily apply their substantive law. See id. at 726, 780 (contending that only states with unique affiliations such as place of incorporation and principal place of business have legislative jurisdiction). The authors observed:

A substantial quantity of unrelated activities also may satisfy these rationales [for adjudicatory jurisdiction].... To the extent that defending in one's domicile is convenient, litigating where one carries on continuous and systematic activities is also likely to be convenient.... [A] test that focuses on continuous and systematic activities eliminates the uncertainty of proving which of several places is the defendant's principal place of business. Most importantly, the reciprocal benefits rationale obtains when the defendant carries out substantial activities, which implicate the police powers and public facilities of the state.

Id. at 741 .

215. See Goodyear Dunlop Tires, 131 S. Ct. at 2854-58 (analyzing the general jurisdiction argument but providing little guidance). 
systematic activity. ${ }^{216}$ On the other hand, the opinion concludes that the total amount of foreign affiliates' contacts showed that the defendants "are in no sense at home in North Carolina" and "fall far short of" the required continuous and systematic business contacts. ${ }^{217}$

The restriction of general jurisdiction to one or two states would effect a radical shift. Under established practice, states may exercise personal jurisdiction over nonresident corporations engaged in business in the state for certain lawsuits. ${ }^{218}$ In Pennoyer, the Court expressly recognized such jurisdiction for lawsuits "instituted with respect to" related business activity in the state. ${ }^{219}$ While Pennoyer authorized specific jurisdiction, the Court in International Shoe observed that due process prohibited general jurisdiction over corporations when corporate ties arose from "the casual presence of the corporate agent or even his conduct of single or isolated" acts unrelated to the claim. ${ }^{220}$ The Court explained that " $[\mathrm{t}] \mathrm{o}$ require the corporation in such circumstances to defend the suit away from its home or other jurisdiction where it carries on more substantial activities has been thought to lay too great and unreasonable a burden on the corporation to comport with due process." 221 Nothing in the traditional line of cases discussing corporate presence for purposes of either specific or general jurisdiction suggests that the tests for presence were aimed at restricting corporate presence to one or two states. ${ }^{222}$ Nor did the corporate defendants in Goodyear Dunlop Tires ask for such a windfall. ${ }^{223}$

216. Id. at 2855 ("[T]ies serving to bolster the exercise of specific jurisdiction do not warrant a determination that, based on those ties, the forum has general jurisdiction over a defendant.” (citing Stabilisierungsfonds Fur Wein v. Kaiser Stuhl Wine Distribs. Pty. Ltd., 647 F.2d 200, 203 n.5 (D.C. Cir. 1981) (Ginsburg, J.))).

217. Id. at 2857 (citing Helicopteros, 466 U.S. at 416).

218. See, e.g., Pennoyer v. Neff, 95 U.S. 714, 735 (1877).

219. Id.

220. Int'l Shoe Co. v. Washington, 326 U.S. 310, 317 (1945).

221. Id. (emphasis added).

222. For example, the Court in International Shoe defines "presence" as merely "activities of the corporation's agent within the state," but the Court never specifies the number of states in which such activity may occur. Id. at 316-17.

223. Petitioners' counsel employed the formula "at home" in oral argument. See Transcript of Oral Argument, supra note 17, at 4-5 (“[G]eneral jurisdiction is about suing ... the corporation essentially where [it is] located or at home. [It is] always fair to bring a suit against the corporation there.”). Petitioners' counsel, however, refrained from proposing being "at home" as the exclusive standard for general jurisdiction, arguing instead that the case was easily decided on existing authority. Id. at 5 (mentioning Helicopteros as one such authority). 


\section{Eliminating Fair Play and Substantial Justice Considerations}

In specific jurisdiction cases prior to 2011, the Court had distinguished the evaluation of minimum contacts creating a sufficient affiliation between the defendant and the forum state from the evaluation of additional factors that could make the exercise of personal jurisdiction fundamentally unfair or unreasonable. ${ }^{224}$ In such cases, the Court employed a two-part analysis that considered (1) minimum contacts and (2) fair play and substantial justice. ${ }^{225}$ In some cases, the presence of facts making the exercise of jurisdiction fundamentally unfair and unreasonable allowed courts to find that personal jurisdiction was unconstitutional without determining whether minimum contacts were present. $^{226}$ For example, the Supreme Court in Asahi, considered five factors concluding that the exercise of personal jurisdiction was so unfair or unreasonable as to violate due process: (1) "the burden on the defendant," (2) "the interests of the forum State," (3) "the plaintiff's interest in obtaining relief," (4) the interest of the interstate or international judicial system in efficiently resolving controversies, and (5) the shared substantive policies of different states. ${ }^{227}$

There is reason to question whether the Court remains committed to this two-part analysis even for specific personal jurisdiction cases. ${ }^{228}$ It

224. See generally Brilmayer et al., supra note 12, at 735-43 (discussing different contacts that establish general or specific jurisdiction and explaining how those contacts influence considerations of fairness and justice).

225. See, e.g., Int'l Shoe, 326 U.S. at 316.

226. See, e.g., Asahi Metal Indus. Co. v. Superior Court, 480 U.S. 102, 113-16 (1987). Although the Justices disagreed on whether minimum contacts existed, eight members of the Court agreed that the exercise of jurisdiction offended traditional notions of fair play and substantial justice. See id. at 116.

227. Id. at 113 (citing World-Wide Volkswagen Corp. v. Woodson, 444 U.S. 286, 292 (1980) (listing the five factors for the first time)).

228. Justice Kennedy's opinion in Nicastro emphasizes the need for in-state activity that is directly attributable to the defendant and repudiates the independent value of fairness considerations to support jurisdiction. See 131 S. Ct. 2780, 2787 (2011) (plurality opinion) ("Freeform notions of fundamental fairness divorced from traditional practice cannot transform a judgment rendered in the absence of authority into law .... [T] [Tose who live or operate primarily outside a State have a due process right not to be subjected to judgment in its courts as a general matter.”).

Criticizing the opinions in Asahi for being imprecise, Justice Kennedy makes clear that "[t]he principal inquiry in cases [such as Nicastro] is whether the defendant's activities manifest an intention to submit to the power of a sovereign.” Id. at 2788. Notably absent is any discussion of the actual basis on which the Court decided Asahi, which indicates that Justice Kennedy no longer finds the two-part analysis helpful. See id. at 2789 (stating that "a rule based on general notions of fairness and foreseeability ... is inconsistent with the premises or lawful judicial power”).

Justice Alito joined Justice Breyer's concurrence, and they concluded that "a single isolated sale” did not establish the necessary minimum contact. Id. at 2792 (Breyer, J., concurring). Their 
was never entirely clear whether analysis of general jurisdiction required a similar two-part consideration of contacts and fairness. ${ }^{229}$ Justice Ginsburg's opinion in Goodyear Dunlop Tires suggests that few, if any, situations require a two-part analysis when evaluating general jurisdiction. $^{230}$

First, the high threshold required to establish general jurisdiction will obviate the concerns that led the Court to consider separately whether

position is consistent with the approach in Justice Stevens' opinion in Asahi where he suggested tentatively that the quantity of products distributed in the state satisfied minimum contacts. Asahi, 480 U.S. at 122 (Stevens, J., concurring).

229. The Supreme Court has never addressed the issue. Lower courts and legal commentators were divided. Some thought that general jurisdiction based on systematic and continuous contacts operated like physical presence and dispensed with the need for evaluating fair play. See, e.g., Robert L. Theriot, Note, Specific and General Jurisdiction-The Reshuffling of Minimum Contacts Analysis, 59 TUL. L. REV. 826, 838-39 (1985) (“The threshold inquiry-whether the defendant's contacts are continuous and systematic — has become determinative of the ultimate inquiry — whether the exercise of jurisdiction is fair and reasonable. In this regard, the Court's treatment of general jurisdiction differs remarkably from its treatment of specific jurisdiction.” (footnote omitted)). Other scholars thought that continuous and systematic contacts satisfied only the minimum contacts requirement and suggested that courts must further evaluate the fairness factors. See Walter W. Heiser, Toward Reasonable Limitations on the Exercise of General Jurisdiction, 41 SAN DIEGO L. REV. 1035, 1042 \& n.26 (2004) (identifying lower court decisions that apply the factors to general jurisdiction cases and opining that "concerns about whether the exercise of jurisdiction is reasonable and fair should actually be heightened in general jurisdiction cases" (citing George, supra note 79, at 1129-41; Mary Twitchell, Why Do We Keep Doing Business with Doing-Business Jurisdiction, 2001 U. CHI. LEgAL F. 171, 196-97); Rhodes, supra note 163, at 899-90 (opining that courts should examine fair play factors when finding general jurisdiction).

Given the uncertainty, one cautious authority counsels a consideration of both substantial contacts and fairness. See MiCHAEL H. HOFFHEIMER, CONFLICT OF LAWS: EXAMPLES AND EXPLANATIONS 44 (2010).

Scholarly proposals often assumed the appropriateness of the two-part analysis. See, e.g., George, supra note 79, at 1129 (proposing a two-part test for general jurisdiction over corporate defendants that considers (1) the "presence of a corporate office within the" State to establish minimum contacts and (2) whether jurisdiction is reasonable by considering "the size and functions of the office" in light of "fair play factors"); Rhodes, supra note 163, at 919 (summarizing a proposed three-prong test for finding general jurisdiction with the first two prongs designed to evaluate minimum contacts based on substantial activity in the forum state and the third prong designed to evaluate notions of fair play and substantial justice). George additionally argues that "[o]nce the minimum contacts threshold is met, as with specific jurisdiction, the fair play factors may serve to affirm the appropriateness of jurisdiction or illustrate its unreasonableness.” George, supra note 79, at 1131 .

230. Justice Ginsburg does not mention a two-part test anywhere in her discussion of general jurisdiction. See Goodyear Dunlop Tires Operations, S.A. v. Brown, 131 S. Ct. 2846, 2854-57 (2011). Justice Ginsburg also cites Asahi only for the proposition that introducing a defective product into the stream of commerce with the expectation that it enter the forum state is insufficient to support specific jurisdiction because such conduct does not establish minimum contacts with the forum. Id. at 2854 (citing Asahi, 480 U.S. at 105). She does not refer to the two-part test used by the Court in Asahi, see id., notwithstanding the fact that the corporations in Goodyear Dunlop Tires invited such analysis. Brief for Petitioners, supra note 117, at 51. 
jurisdiction is fundamentally fair or reasonable. ${ }^{231}$ Requiring continuous and systematic contacts comparable to the defendants' legal home assures that such states will have real interests in providing forums, and it protects corporate defendants from the burden of litigating in seriously inconvenient places. ${ }^{232}$ Second, the Court's emphasis on the nexus between the defendant and the forum state, ${ }^{233}$ coupled with the absence of any hint that courts should consider fundamental fairness factors, ${ }^{234}$ indicates that the Court considers the forum state's interest and the plaintiffs' interest as irrelevant to the determination of general jurisdiction. ${ }^{235}$

In any event, the Court explains that such factors never permit the exercise of general jurisdiction outside of a place with which the defendant has continuous and systematic contacts comparable to its place of incorporation or principal place of business. ${ }^{236}$ Thus, the only possible surviving use of factors such as the plaintiffs' and forum's interests would be to eliminate jurisdiction in a case where, despite the presence of systematic and continuous contacts, other considerations militate against jurisdiction. ${ }^{237}$

\section{E. The Middle Path}

Between the narrow and broad readings of the opinion in Goodyear Dunlop Tires lies a third option. On the one hand, courts should apply the holding to a range of cases that do not fall within the Court's narrow

231. See Theriot, supra note 229, at 838-39.

232. See Heiser, supra note 229, at 1042-43 (stating that avoiding inconvenience and burdens on defendants' is the "primary concern in assessing the 'reasonableness' of personal jurisdiction").

233. See Goodyear Dunlop Tires, 131 S. Ct. at 2851 (requiring a "continuous and systematic" affiliation).

234. See supra Part IV.D.4.

235. See supra Part IV.C.2.

236. The Court definitively rejects the proposal advanced by some authors that weaker contacts may be strengthened by the presence of factors making general jurisdiction reasonable. See Goodyear Dunlop Tires, 131 S. Ct. at 2855 (stating that factors supporting specific jurisdiction do not warrant a finding of general jurisdiction). Cf. Heiser, supra note 229, at 1049 (discussing sliding-scale tests used by lower courts).

237. Such a case would arise if a North Carolina court subjected a corporation like Goodyear USA to general jurisdiction in North Carolina based solely on its manufacturing and marketing activity in the state, even though the claims involved a defective product manufactured and marketed outside North Carolina, which caused injury outside the state. The Constitution might prohibit personal jurisdiction over such a civil action if neither the forum state nor the plaintiff had legitimate interests in litigating in a North Carolina forum, especially if North Carolina's exercise of jurisdiction interfered with the authority of other sovereigns with an interest in the dispute. 
framing of the issue but that cannot be meaningfully distinguished from the facts of the case. ${ }^{238}$ On the other hand, courts should avoid applying the opinion's broad doctrinal language to situations that differ significantly from the facts presented in Goodyear Dunlop Tires.

1. The Court Did Not Expressly Limit the Decision to Sporadic Sales of Manufacturers' Products Through Intermediaries

The narrowest possible reading of the opinion is not a fair reading of the decision. On the contrary, the Court understood that its decision approved of and added to jurisprudence that allowed general jurisdiction at a corporation's sole place of business ${ }^{239}$ and that prohibited general jurisdiction based on purchases and related physical corporate presence in the state. ${ }^{240}$ Justice Ginsburg meant for the opinion to explain the common ground of these decisions.

Although the opinion framed issues narrowly, nothing in the Court's reasoning limits its scope to foreign manufacturers or even to buyers and sellers. The decision would thus apply with equal force to business entities that acquire products after the initial manufacturing and to outof-state businesses that provide services in the forum state. Despite the Court's characterization of the facts to emphasize the sporadic nature of the sales and the role of intermediaries, ${ }^{241}$ it is questionable whether a fair reading of the opinion limits the holding to such circumstances. Given the Court's lack of attention to the role of intermediaries, ${ }^{242}$ the opinion strongly suggests that even limited quantities of direct sales by themselves will not establish general jurisdiction over a foreign corporate vendor. $^{243}$

238. Read most narrowly, the decision leaves unanswered most questions about general jurisdiction, such as whether a state may exercise general jurisdiction over a manufacturer that sells a large volume of products in the forum state or targets its sales through in-state subsidiaries. Cf. Friedrich Juenger, The American Law of General Jurisdiction, 2001 U. CHI. LEGAL F. 141, 158 (identifying similar questions that were unanswered by the Court's jurisprudence as of 2001).

239. See supra notes $148-51$ and accompanying text.

240. See supra text accompanying notes 151-52.

241. See Goodyear Dunlop Tires, 131 S. Ct. at 2856.

242. See id. at 2850, 2856 (using the term “intermediaries” only once).

243. Dictum in a footnote drops all qualifications that the holding applies only to sporadic sales through intermediaries: "As already explained .... even regularly occurring sales of a product in a State do not justify the exercise of jurisdiction over a claim unrelated to those sales." Id. at 2857 n.6. Despite this dictum, the Court nowhere previously opined that regular direct sales were constitutionally insufficient for general jurisdiction. 


\section{The Court Disfavors General Jurisdiction Based on Corporate}

Activities or Contacts at a Place Other than the Place of Incorporation or Principal Place of Business

Courts should avoid leaping to the broadest possible application of Goodyear Dunlop Tires and avoid reading it as eliminating general jurisdiction except in states where a corporation is incorporated or maintains its principal place of business. The opinion itself contains language that suggests that there can be other states where a corporation has such substantial, continuous, and systematic business contacts that those states may constitutionally exercise general jurisdiction. ${ }^{244}$ Nevertheless, a fair reading of the opinion leaves little doubt that circumstances giving rise to general jurisdiction will be unusual. While the Court may not have completely eliminated general jurisdiction based on contacts, it makes clear that only extraordinarily high levels of activity may support such general jurisdiction. ${ }^{245}$

\section{IMPLICATIONS FOR PRACTICE}

\section{A. The Big Picture: General Jurisdiction in Context}

\section{Expanding the Gaps and Shrinking the Gap Filler}

Plaintiffs infrequently utilize general jurisdiction theories, "suggesting the difficult nature of succeeding under that approach." ${ }^{, 46}$ In some cases, however, where specific jurisdiction is not available, general jurisdiction provides the only form of jurisdiction. For cases where a state does not authorize specific jurisdiction, general jurisdiction

244. See id. at 2852, 2856-57 (discussing the location and quantity of sales of defendants' tires in North Carolina and emphasizing only that sporadic sales are insufficient).

245. See discussion supra note 244. Prior to Goodyear Dunlop Tires, one authority warned that "counsel who attempts to bring a case on the theory of general jurisdiction in a forum in which the defendant has no obvious physical presence had best make alternative plans for pursuing the case elsewhere in the event that the forum concludes that it lacks jurisdiction." PETER HAY ET AL., CONFLICT OF LAWS $\S 6.9$, at 412 (5th ed. 2010). This warning should now include attempts to assert general jurisdiction anywhere other than the place of incorporation or principal place of business.

246. Michael E. Solimine, The Quiet Revolution in Personal Jurisdiction, 73 TUL. L. REV. 1, 38

(1998). Professor Solimine's empirical study found that twelve percent of cases invoked general jurisdiction. Id. Numerous decisions purporting to find general jurisdiction do so in disputes where in-state contacts gave rise to the litigation. See Rhodes, supra note 163, at 820-21. Some scholars even claim general jurisdiction is "rare." See, e.g., Twitchell, supra note 103, at 630 (contending that, with the rise of specific jurisdiction, "the exercise of general jurisdiction has become rare"). 
provides a gap-filling function, allowing state courts to exercise jurisdiction over a broader range of cases provided that the exercise of general jurisdiction does not violate due process rights. ${ }^{247}$

Justice Ginsburg, in Goodyear Dunlop Tires, endorses a theory of general jurisdiction proposed in the 1960s and 1970s by scholars with a specific reform agenda. Seeking to rationalize and generalize the Court's personal jurisdiction cases, von Mehren and Trautman had assumed that specific jurisdiction was expanding and would someday reach the point where state courts could constitutionally exercise jurisdiction over all cases in which the state had an interest or state residents were affected. ${ }^{248}$ Given this expansion, the authors argued that "ultimately only general jurisdiction and specific jurisdiction should be recognized, and the only relationship basing general jurisdiction should... be [the] habitual residence except [when] the defendant has no substantial connection with any community."249 Accordingly, they proposed eliminating in rem jurisdiction and jurisdiction based on in-state personal service when the claims did not arise out of or relate to the defendant's activity in the state.”250 They also proposed-with remarkable little attention to caselaw $^{251}$ - that the gap-filling function of general jurisdiction would be satisfied by limiting it to one place where a defendant could always be forced to litigate. ${ }^{252}$ Brilmayer and her coauthors published a proposal that differed in details but shared the assumption that a restriction of general jurisdiction would not reduce the scope of state judicial power because of the concurrent expansion of specific jurisdiction. ${ }^{253}$

247. See Borchers, supra note 18, at 130-32 (arguing that general jurisdiction fills gaps left by three major deficiencies in specific jurisdiction). Because general jurisdiction provides an important supplement to specific jurisdiction, Borchers observes that "abolishing general jurisdiction might be a more palatable alternative if specific jurisdiction operated more sensibly. But as things stand, abolishing general jurisdiction would make a bad situation worse.” Id. at 132.

248. For example, they argued that states should have jurisdiction over cases where residents did not leave the state but were injured by wholly out-of-state defendant activity. Von Mehren \& Trautman, supra note 3 , at $1167-68,1172$.

249. Id. at 1177.

250. Id. at 1164-65, 1177.

251. Id. at 1141-42 (citing no cases for general jurisdiction at principal place of business).

252. For individuals, this place was domicile or habitual residence. Id. at 1177 . For corporations, scholars were less sure which place was appropriate. Some assumed that the place of incorporation was valid but also recognized the principal place of business. Id. at 1179 (proposing general jurisdiction at the place of corporate headquarters and defining corporate headquarters to include "both the place of incorporation and the principal place of business").

253. See Brilmayer et al., supra note 12, at 782 (arguing that specific jurisdiction stems from a forum's right to regulate in-state activities); see also Twitchell, supra note 103, at 675-76 (expressly linking her proposed restriction of general jurisdiction to her proposed expansion of specific personal jurisdiction). 
Decades of cases have revealed that expectations of a rational expansion of specific personal jurisdiction were unfounded. The Court has repudiated efforts to formulate a broad theory of jurisdiction based on reason and fairness, ${ }^{254}$ retreated from cases that authorized specific jurisdiction based on harm caused in the forum state, ${ }^{255}$ and inched towards a vision of substantive due process where a defendant must submit to jurisdiction through some affirmative act of will and can, correspondingly, structure extraterritorial activity so as to be immune to jurisdiction. ${ }^{256}$ Justice Ginsburg's opinion, adopting half of a theory proposed by reform-minded scholars over thirty years ago, does not produce a coherent theory of jurisdiction. It results in a reduction of state jurisdiction that reformers never anticipated.

\section{Too Many Metaphors}

Rather than explaining the reasons for general jurisdiction ${ }^{257}$ Justice Ginsburg's opinion in Goodyear Dunlop Tires proposes a new metaphor

254. See J. McIntyre Mach, Ltd. v. Nicastro, 131 S. Ct. 2780, 2789 (2011) (plurality opinion) (noting that "general fairness considerations [are not] the touchstone of jurisdiction"). Justice Brennan's separate opinions offer the most ambitious formulation of an approach to personal jurisdiction based on reasonableness and fairness. See, e.g., Helicopteros Nacionales de Colom., S.A. v. Hall, 466 U.S. 408, 419-28 (1984) (Brennan, J., dissenting) (asserting that fairness and the expansion and ease of conducting business warranted finding jurisdiction where the defendants engaged in some business in the forum); World-Wide Volkswagen Corp. v. Woodson, 444 U.S. 286, 317-19 (1980) (Brennan, J., dissenting) (arguing that sufficient contacts and economic benefits would make it fair to find specific jurisdiction); Shaffer v. Heitner, 433 U.S. 186, 225 (1977) (Brennan, J., concurring in part and dissenting in part) (asserting that relevant considerations include party expectation and fairness).

255. Compare World-Wide Volkswagen, 444 U.S. at 298 (majority opinion) (explicitly approving of pure stream-of-commerce jurisdiction), with Asahi Metal Indus. Co. v. Superior Court, 480 U.S. 102, 112 (1987) (plurality opinion) (holding that placing a product into the stream of commerce does not establish minimum contacts), and Nicastro, 131 S. Ct. at 2791 (repudiating the stream-ofcommerce metaphor).

256. Justice Kennedy articulates the theory that substantive due process-presumably natural law outside the United States - guarantees a realm in which legal actors are free from the power of states absent some conduct by which they volitionally submit to both legislative and adjudicatory jurisdiction. See Nicastro, 131 S. Ct. at 2787 ("[T] hose who live or operate primarily outside a State have a due process right not to be subjected to judgment in its courts as a general matter.”) Thus, a corporation is free from a state's personal jurisdiction unless it incorporates under the laws of the state, maintains its principal place of business in the state, or is responsible for some conduct in the state that gives rise to the lawsuit. See id. (stating that a corporation's presence includes being incorporated or having its principal place of business in the forum).

257. There is reason to suppose the Justices could not reach agreement on the underlying principles that support general jurisdiction. Cf. Nicastro, 131 S. Ct. at 2799 (Ginsburg, J., dissenting) (sharply criticizing the plurality's submission theory of jurisdiction). 
to help courts grapple with problems of general jurisdiction. ${ }^{258}$ In determining whether a state has general jurisdiction over a foreign corporation, lower courts must now ascertain whether the defendant is incorporated in, maintains a principal place of business in, or is otherwise "at home" in the forum state.

Justice Ginsburg does not propose the "at home" metaphor as a substitute for older metaphors of substantial activity or continuous and systematic contacts in the state. The new metaphor supplements the older metaphors and encourages courts to apply the old metaphors in a more restrictive fashion. Yet determining whether a corporation is "at home" will itself require an inquiry into "activity" and "contacts," which are themselves metaphors that were promulgated as aids to determining whether a corporation had achieved sufficient "presence."

\section{B. The Little Picture: The Unknown}

1. Where Is the Place of Incorporation?

It has long been recognized that a state has general jurisdiction over a corporation incorporated under its law. ${ }^{259}$ The reason for this is not obvious, however, and Goodyear Dunlop Tires sheds no light on the matter. The Court's metaphorical reference to a corporation being "at home" in its place of incorporation seems merely to repeat the old view that a corporation's "domicile" is its place of incorporation. ${ }^{260}$ The opinion's restriction of general jurisdiction outside the place of incorporation will force plaintiffs to bring actions more often in the place of incorporation, even when that place is problematic.

258. It might have been useful for the Court to consider the theories and metaphors that lower courts had employed in the absence of guidance from the Court, including the Ninth Circuit's success with the "at home" metaphor. See infra note 288.

The petitioners proposed a rule that would require the Court to attribute some in-state property or act directly to the defendant as a necessary, but independently insufficient, ground for general jurisdiction. See supra note 223.

259. See Pennoyer v. Neff, 95 U.S. 714, 735-36 (1887) ("Nor do we doubt that a State, on creating corporations ... may provide a mode in which their conduct may be investigated, their obligations enforced, or their charters revoked, which shall require other than personal service upon their officers or members.”); see also supra notes 200 and 256.

260. See supra note 184. Cf. Nicastro, 131 S. Ct. at 2787 (plurality opinion) (citing Goodyear Dunlop Tires Operations, S.A. v. Brown, 131 S. Ct. 2846, 2894 (2011)) (explaining that a corporation's submitting to a sovereign's laws evidences "general submission to a State's powers"). 
Scholars originally proposed general jurisdiction at the place of incorporation as a single, easily identifiable fall-back jurisdiction. ${ }^{261}$ But the place of incorporation is not necessarily singular or fixed. Corporations need not have only one state of incorporation. ${ }^{262}$ Federal law may give rise to the existence of corporate entities, preventing any individual state from qualifying as the place of incorporation, ${ }^{263}$ and foreign legal systems may present similar challenges. Businesses can have de facto corporate existence in one state yet be recognized as a partnership in another. ${ }^{264}$ And corporations change their place of incorporation in the midst of litigation. ${ }^{265}$

\section{Where Is the Principal Place of Business?}

Further uncertainty attends the authority and justification for the doctrine that a corporation is subject to general personal jurisdiction in the state in which it maintains its principal place of business. ${ }^{266}$ Von

261. See supra note 200.

262. See Charles Alan Wright, Law of Federal Courts § 27, at 166 (5th ed. 1994); see also Donald T. Weckstein, Multi-State Corporations and Diversity of Citizenship: A Field Day for Fictions, 31 TENN. L. REV. 195, 210 (1964).

263. See, e.g., 36 U.S.C. § 30901(a) (2006) (incorporating the Boy Scouts of America in the District of Columbia).

264. See, e.g., Paper Prods. Co. v. Doggrell, 261 S.W.2d 127, 128-29 (Tenn. 1953) (distinguishing recognition of a de facto corporation when a charter is not filed as a matter of Tennessee law from disregard of corporate existence and treatment of resulting business as partnership under Arkansas law).

265. E.g., Black \& White Taxicab Co. v. Brown \& Yellow Taxicab Co., 276 U.S. 518, 523-24 (1928).

266. An early statement of a general principle appeared in 1875: "The general rule is that a corporation can be sued only in the place where it was created - within the jurisdiction where it was born, and where its principal place of business is located.” Bawknight v. Liverpool \& London \& Globe Ins. Co., 55 Ga. 194, 195 (1875), overruled in part by Newberry v. Tenant, 121 Ga. 561 (1904). Moreover, at this early date, courts already understood that foreign corporations were subject to jurisdiction based on debts arising in state provided only that a corporate agent received service in the state. Id. at 196 . Corporate assets located in the state could be seized to satisfy unrelated claims. Id. at 197. In other words, courts recognized broad forms of specific jurisdiction and quasi in rem general jurisdiction. In contrast, under the facts presented, the Georgia Supreme Court held that there was no jurisdiction to enforce a sister-state judgment unrelated to the corporation's activity in the state and based its holding on lack of statutory authorization. Id.

Jurisdictional practice in other states differed. See, e.g., Stephenson Ins. Co. v. Dunn, 45 Ill. 211, 213 (1867) (asserting that jurisdiction would be proper over an Illinois corporation in the county where the corporate agent was served even though the principal place of business was in another country (citing Peoria Ins. Co. v. Warner, 28 Ill. 429, 429 (1862))). Courts did not clearly define borders between venue, personal jurisdiction, and subject matter jurisdiction. Thus, one case held that suit against a domestic corporation in a county outside the corporation's principal place of business "turns on the subject matter" and cannot be waived. Ga. R.R. \& Banking Co. v. Seymour, 
Mehren and Trautman provide no legal authority for the doctrine, ${ }^{267}$ and the rule probably arose as a generalization of the accepted practice by which service on an authorized agent at the corporation's headquarters satisfied notice requirements and established a firm basis for personal jurisdiction for all claims against the corporation. ${ }^{268}$

The Goodyear Dunlop Tires opinion neither explains the rule nor offers guidance about how to define the appropriate principal place of business for purposes of personal jurisdiction. ${ }^{269}$ This invites confusion because the Court recently resolved longstanding problems with respect to the definition of "principal place of business" in the federal diversity statute $^{270}$ by defining a corporation's principal place of business as "the place where the corporation's high level officers direct, control, and coordinate the corporation's activities."271 Because the Court offers no explanation for why personal jurisdiction exists at the corporation's

53 Ga. 499, 500-01 (Ga. 1874), overruled in part by Lamb v. Howard, 102 S. 436 (Ga. 1920).

Early statutes fixing jurisdiction at a "principal place of business" might have meant to designate the place so identified in the charter rather than the actual headquarters or center of business activity. The difference is significant in insolvency proceedings-much on the minds of early legislators-where litigation may occur after a corporation forms but before it begins operations. See Coggil v. Botsford, 29 Conn. 439, 446-47 (1861) (discussing a statute restricting proceedings against insolvent debtors for certain debts to probate court where partnership or corporation had its principal place of business).

267. See von Mehren \& Trautman, supra note 3, at 1141-42 (observing that a state where a corporation was incorporated and maintained its head office would be "analogous to that of the community of natural person's domicile and habitual residence”). The authors speculated that if a corporation split its administrative offices from its place of incorporation, then "presumably general jurisdiction should exist in either community.” Id. at 1142 (emphasis added). Without explaining why the place of administration should support jurisdiction, von Mehren and Trautman suggest that multiple places could exercise jurisdiction when a corporation decentralizes its administration: "[I]f top-level managerial and administrative functions are centered rather equally in two or more communities, each such community has a legitimate claim to be treated as the corporation's head office for jurisdictional purposes.” Id.

268. See, e.g., FED. R. CIV. P. 4(h)(1) (authorizing service on a corporation by delivery of the summons and the complaint to "an officer, a managing or general agent, or any other agent authorized ... to receive service").

269. See Goodyear Dunlop Tires Operations, S.A. v. Brown, 131 S. Ct. 2846, 2854 (2011) (mentioning the phrase "principal place of business" but never defining it (citing Brilmayer et al., supra note 12 , at 728)).

270. "For the purposes of [diversity and removal jurisdiction] a corporation shall be deemed to be a citizen of any State by which it has been incorporated and of the State where it has its principal place of business ....” 28 U.S.C. § 1332(c)(1) (2006). The definition of corporate citizenship to include "principal place of business" was added in 1958. Act of July 25, 1958, Pub. L. No. 85-554, 72 Stat. 415 (codified as amended at 28 U.S.C. § 1332(c)). See generally WRIGHT, supra note 262, at 163.

271. Hertz Corp. v. Friend, 130 S. Ct. 1181, 1186 (2010). The Court adopted the "nerve center" test for identifying the principal place of business and explained that this will "normally be the place where the corporation maintains its headquarters.” Id. at 1192. 
principal place of business, lower courts familiar with the nerve-center test may apply that test to matters of personal jurisdiction.

This is unfortunate because it is questionable whether the principal place of business should be defined the same way for both subject matter jurisdiction and personal jurisdiction. ${ }^{272}$ In adopting the nerve-center test, the Court relied on the unique factors underpinning diversity jurisdiction, including the administrative simplicity of applying the statute and the legislative history of the statutory language. ${ }^{273}$ The Court offered a prudential construction of a statute fully aware that Congress could amend the statute to achieve a different result. ${ }^{274}$ By assigning citizenship to corporations in the state of their principal place of business, Congress intended to multiply corporate citizenship and, thus, reduce federal court subject matter jurisdiction in diversity cases. ${ }^{275}$ In contrast, assigning general jurisdiction at the principal place of business expands personal jurisdiction when a corporation establishes its center of operations in a place outside the state of incorporation. ${ }^{276}$

The nerve-center test provides one workable method for determining corporate citizenship. The test may even provide one constitutionally appropriate method for determining general jurisdiction. ${ }^{277}$ But the test does not necessarily provide the optimal definition for principal place of business when a corporation has substantial activity and greater contacts

272. Gene R. Shreve \& Peter RAVEn-HAnsen, Understanding Civil Procedure § 3.03, at 34 (4th ed. 2009) ("It would be tempting to resolve personal jurisdiction issues by reference to th[e] case law [defining principal place of business for diversity purposes], but this is probably unwise. The due process law of personal jurisdiction and the law of federal subject matter jurisdiction are grounded on fundamentally different policies.”).

273. Hertz, 130 S. Ct. at 1193-94. The Court also relied on the fact that the "principal place" in the diversity statute meant one localized place like an office. Id. at 1192-93 (citing 12 OXFORD ENGLISH DICTIONARY 495 (2d ed. 1989)). On the contrary, discussions of general jurisdiction at the principal place of business typically assume jurisdiction exists throughout the state. See, e.g., J. McIntyre Mach., Ltd. v. Nicastro, 131 S. Ct. 2780, 2787 (plurality opinion) (finding that a principal place of business in the forum state subjects the corporation to general jurisdiction in that state).

274. See Hertz, 130 S. Ct. at 1194.

275. See id. at 1187-90 (discussing the reasons behind the 1958 amendment to federal diversity jurisdiction).

276. Federal courts may exercise personal jurisdiction over a corporate defendant that is subject to personal jurisdiction in the state courts of the state where the federal court is located. FED. R. CIV. P. 4(k)(1)(A).

277. The test identifies one of the administrative centers that von Mehren and Trautman endorsed as appropriate places for unlimited general jurisdiction. Compare von Mehren \& Trautman, supra note 3, at 1141-42 ("If a corporation's managerial and administrative center is in a state other than its state of incorporation, [then] presumably general jurisdiction should exist in either community.”), with Hertz, 130 S. Ct. at 1192-93 (suggesting that the principal place of business, which is usually a business's headquarters, identifies a single locus for the "direction, control, and coordination” of the corporation). 
elsewhere. Principles of federalism and the Erie doctrine ${ }^{278}$ may counsel against formulating any uniform definition and in favor of deferring to state law definitions. And as a matter of substantive law, courts may have good reasons for rejecting the nerve-center test as a particularly inappropriate guide for identifying a corporation's principal place of business for purposes of personal jurisdiction. ${ }^{279}$

\section{When Do Activity and Contacts Make a Home?}

The Goodyear Dunlop Tires decision offers little guidance about when substantial corporate activity that establishes continuous and systematic business contacts also supports a finding that the corporation is "at home" outside of its places of incorporation and principal place or places of business. ${ }^{280}$ Considering the application of the decision's standards to the defendant Goodyear USA, which had consented to personal jurisdiction, illustrates the uncertainty of the decision. Goodyear USA was not incorporated in North Carolina, ${ }^{281}$ did not maintain its corporate headquarters in the state, ${ }^{282}$ and conducted much of its manufacturing or sales business outside the state. ${ }^{283}$ Nevertheless, Goodyear USA operated a factory in North Carolina and engaged in a large volume of sales in the state. ${ }^{284}$

On the one hand, plaintiffs could argue that Goodyear USA has the sort of "continuous and systematic" affiliations that make it "essentially at home" and thus subject to general jurisdiction in North Carolina. On the other hand, Goodyear USA could counter that North Carolina, despite such contacts, is not an "equivalent place" to domicile in which the corporation is regarded "at home." ${ }^{285}$ Early signals from lower courts suggest that they will dutifully repeat the new "at home" metaphor but

278. Erie R.R. Co. v. Tompkins, 304 U.S. 64, 78-80 (1938) (holding that federal courts must apply state substantive law in diversity cases).

279. The location of executive offices has no necessary relationship to corporate activity that generates business or that constitutes the contacts and presence traditionally required for general jurisdiction. In fact, corporations can relocate executive offices to distant sites for reasons unrelated to their business activities. See, e.g., Clifford Krauss, Halliburton Office Move Is Criticized, N.Y. TIMES, March 13, 2007, at C1 (describing the move of military contractor Halliburton's headquarters from Houston, Texas, to Dubai despite continuing extensive business within the United States).

280. See supra Part IV.C.2.

281. Goodyear Dunlop Tires Operations, S.A. v. Brown, 131 S. Ct. 2846, 2852 (2011).

282. See supra note 120.

283. See supra note 120.

284. Goodyear Dunlop Tires, 131 S. Ct. at 2850.

285. Id. at 2853-54. 
will not find it a meaningful guide in their analysis of the kind of corporate behavior that will render general jurisdiction constitutional. ${ }^{286}$

\section{Does Service on an Agent Authorized to Receive Process Establish General Jurisdiction?}

The Court's decision in Goodyear Dunlop Tires does not resolve an issue on which lower courts have been divided: whether service of process on an agent appointed by a corporation to receive process ${ }^{287}$ establishes valid general jurisdiction. ${ }^{288}$ During oral argument, Justices on the Court expressed keen interest in this issue. ${ }^{289}$

286. In Viasystems, Inc. v. EBM-Pabst St. Georgen GmbH \& Co., Judge Gruender quoted Goodyear Dunlop Tires' "at home” language but did not apply it to the jurisdictional analysis. 646 F.3d 589, 595-98 (8th Cir. 2011) (affirming dismissal for lack of personal jurisdiction in an action brought in Missouri by a St. Louis manufacturer for damages allegedly caused by products it bought from a German manufacturer and later installed on its own product in China by plaintiff's subsidiary). In rejecting the argument that delivery of products by a subsidiary supported general jurisdiction, Judge Gruender observed that Goodyear Dunlop Tires held that placing products in the stream of commerce will not support general jurisdiction-a rule previously established by Eighth Circuit authority. Id. at 597 (noting that stream-of-commerce jurisdiction is relevant only for purposes of specific jurisdiction) (citing Barone v. Rich Bros. Interstate Display Fireworks Co., 25 F.3d 610, 612 (8th Cir. 1994)).

In Francis v. Bridgestone Corp., Judge Finch quoted Goodyear Dunlop Tires' “at home” language but found that the defendant had no direct contact with the forum state. No. 2010/30, 2011 U.S. Dist. LEXIS 72804, at *24, *26-27 (D.V.I. July 6, 2011) (rejecting the theory of general jurisdiction as untenable but permitting limited discovery on whether specific jurisdiction existed over the defendant alleged to have distributed a defective tire in the Virgin Islands where it caused injury). The court found that, even if another entity's acts were attributable to the defendant, that entity lacked "systematic and continuous contacts with [the Virgin Islands]." Id. at*34. The court quoted Goodyear Dunlop Tires in rejecting stream-of-commerce activity as a basis for general jurisdiction. Id. at *28 n.17.

287. Every state requires foreign corporations to register and appoint agents for service of process. Rhodes, supra note 163, at 856.

288. See, e.g., King v. Am. Family Mut. Ins. Co., 632 F.3d 570, 579 (9th Cir. 2010) (applying the Ninth Circuit's "at home" requirement and prohibiting general jurisdiction where one of defendant's few contacts was an agent appointed to receive process). See generally Lee Scott Taylor, Note, Registration Statutes, Personal Jurisdiction, and the Problem of Predictability, 103 Colum. L. REV. 1163, 1181-92 (2003) (discussing the circuit split over whether service on an agent appointed pursuant to registration statute establishes general jurisdiction).

289. Justice Kagan asked Petitioners' counsel if general jurisdiction would be proper over Goodyear USA if it had not consented. Transcript of Oral Argument, supra note 17, at 4. Justice Ginsburg asked the Assistant Solicitor General, who appeared as amicus curiae, whether general jurisdiction would be proper based on service of an agent appointed by a corporation that otherwise lacked continuous and systematic contacts. Id. at 15. Responses from both counsel alerted the Court to the split of authority among the lower courts. Id. at 5-6, 15-18. In this posture, the Court's failure to address the issue in its unanimous opinion suggests a deliberate decision to leave the matter open. 
Opinions in both Goodyear Dunlop Tires and Nicastro contain statements that general jurisdiction over corporations exists in the state where the corporation is "at home," identified as its place of incorporation or principal place of business. ${ }^{290}$ Because the opinions do not further qualify such statements, it is possible to read them as signaling obliquely that the method of service is unimportant.

This is not a plausible reading. The Court similarly observes, without qualification, that general jurisdiction over an individual is proper in the courts of his or her domicile. ${ }^{291}$ This observation hardly signals that the Court intends to overrule its holding that personal service establishes valid general jurisdiction over an individual. ${ }^{292}$ In describing the places where corporations are "at home" as analogous to an individual's domicile, ${ }^{293}$ the Court leaves open the possibility that traditional methods of service on corporate agents may also support general jurisdiction analogous to service on an individual.

\section{Can Individuals Have a Contacts-Based Place Where They Are “At}

Home” Different From Their Domicile or Residence?

The Goodyear Dunlop Tires decision does not involve personal jurisdiction over individuals. ${ }^{294}$ By treating general jurisdiction over corporations based on continuous and systematic contacts as analogous to jurisdiction at an individual's domicile, ${ }^{295}$ the Court may be signaling that such contacts will not separately establish a basis for general jurisdiction over an individual outside the individual's domicile or residence. If so, then individuals will be subject to general jurisdiction only at their place of domicile and in states where they are served with process. If the Court has reached a consensus that contacts and activity do not support general jurisdiction over individuals, then it should have

290. Goodyear Dunlop Tires, 131 S. Ct. at 2850-51, 2854, 2857; see also J. McIntyre, Ltd. v. Nicastro, 131 S. Ct. 2780, 2797 (2011) (plurality opinion) (citing Goodyear Dunlop Tires, 131 S. Ct. at 2850-51, 2854-57).

291. Goodyear Dunlop Tires, 131 S. Ct. at 2853; Nicastro, 131 S. Ct. at 2787 (citing Goodyear Dunlop Tires, 131 S. Ct. at 2854).

292. See supra note 183.

293. See, e.g., Nicastro, $131 \mathrm{~S}$. Ct. at 2787 (making a comparison between domicile and place of incorporation) (citing Goodyear Dunlop Tires, 131 S. Ct. at 2854); see also supra notes 200-01 and accompanying text.

294. See supra note 3 and accompanying text.

295. See supra note 293 and accompanying text. 
said so. It is questionable whether lower courts will so construe the opinion. ${ }^{296}$

\section{Easy Cases After Goodyear Dunlop Tires}

The Goodyear Dunlop Tires decision, read with Perkins and Helicopteros, definitively answers the question of whether states may exercise general jurisdiction over corporations in several recurring situations. Justice Ginsburg's comparative evaluation of in-state and outof-state sales $^{297}$ indicates that a state may exercise jurisdiction over a corporation that completes most of its sales in the state, and her reasoning applies equally to other business activity. ${ }^{298}$ Conversely, the presence of a permanent purchasing agent, either a corporation or an individual, in a state will not be enough to establish general jurisdiction over a nonresident corporation that conducts most of its business out of state. ${ }^{299}$ Similarly, the presence of nonexclusive sales agents will not

296. Less than two months after Goodyear Dunlop Tires, a federal court cited the opinion in a decision finding general jurisdiction over a nonresident individual based on continuous and systematic contacts of a corporation that the court regarded as the individual's surrogate. Harrelson v. Seung Heun Lee, No. 09-11714-RGS, 2011 U.S. Dist. LEXIS 79383, at *20 (D. Mass. July 21, 2011) (denying a motion to dismiss and finding general jurisdiction in Massachusetts over an Arizona citizen for rape allegedly committed in South Korea), dismissed by 2012 U.S. Dist. LEXIS (D. Mass. Jan. 31, 2012). The court quoted Justice Ginsburg's edict that "the paradigm forum for the exercise of general jurisdiction is the individual's domicile." Id. at *11 (quoting Goodyear Dunlop Tires, $131 \mathrm{~S}$. Ct. at 2853). The trial judge, however, found general jurisdiction over the individual based on his domination and control of the yoga network, thus supporting piercing the corporate veil. Id. at *13-14, *17.

297. See Goodyear Dunlop Tires, 131 S. Ct. at 2856-57 (comparing defendants' sales to the level of activity in Perkins and Helicopteros).

298. While the Court in Helicopteros Nacionales held that purchases and related visits to the forum are not enough to support general jurisdiction, it did so in a case where the defendant was engaged primarily in providing transportation services outside of Texas. See 466 U.S. 408, 409-10, 418 (1984). The decision does not preclude general jurisdiction over a corporation that engages solely in purchasing that occurs mainly in the forum state. On the contrary, in such a case general jurisdiction would be proper either because the forum state is the corporation's principal place of business or because the defendant has sufficient continuous and systematic contacts to make the state its legal home.

The Court's comparative treatment of selling activity in Goodyear Dunlop Tires seems to support general jurisdiction in the state where most of the direct purchases or sales occur, regardless of whether the corporation maintains some physical presence in that state. See supra notes 162-63 and accompanying text (discussing comparisons of overall sales and their impact on jurisdiction). The outcome is less certain in cases where the corporation acts through by intermediaries or where a corporation engages in additional types of activity, such as when it engages in a plurality of sales or purchases in the forum state but engages in the majority of purchases or sales in other states.

299. This is implied by the Court's holding in Helicopteros where the corporate defendant maintained a permanent presence of rotating agents in the state. See supra note 112. 
subject a nonresident corporation to general jurisdiction in a state where it does not do most of its business. ${ }^{300}$

Additional facts like the presence of permanent offices, warehouses, or substantial assets in the forum will help support a finding of general jurisdiction. Such facts will not be present when corporations engage solely in interstate commerce over the Internet. ${ }^{301}$ When a corporation engages in most of its commercial activity in one state, that state may properly exercise general jurisdiction consistent with the Due Process Clause. $^{302}$ It is less clear whether a state might properly exercise jurisdiction when the nonresident corporation engages in a higher volume of sales in that state than in any other, or when most of its activity is spread among a few states. ${ }^{303}$

The Court's categorical distinction in Goodyear Dunlop Tires between specific and general jurisdiction-together with its insistence that contacts enhancing specific jurisdiction do not establish a proper basis for general jurisdiction ${ }^{304}$ - suggest an answer to a recurring

300. This is implied by the Court's treatment of sales in Goodyear Dunlop Tires. Though the Court refused to attribute contacts to the foreign corporations based on a single-enterprise theory, Goodyear USA apparently placed orders to and on behalf of the foreign affiliates. $131 \mathrm{~S}$. Ct. at 2852, 2857. The Court did not discuss agency, which may indicate its irrelevance to the Court. Solicitation of sales for the foreign affiliates was merely incidental to other local business of Goodyear USA because it was not the exclusive sales agency for the foreign corporations. See id. at 2852.

301. There is growing criticism of the judicial tests and potentially overbroad exercise of jurisdiction based on Internet contacts. See, e.g., Eric C. Hawkins, Note, General Jurisdiction and Internet Contacts: What Role, If Any, Should the Zippo Sliding Scale Test Play in the Analysis?, 74 FORDHAM L. REV. 2371, 2387-89 (2006) (discussing criticism of a judicial test for general jurisdiction over defendants engaged in Internet commerce as resulting in excessive flexibility and uncertainty); Quinn K. Nemeyer, Comment, Don't Hate the Player, Hate the Game: Applying the Traditional Concepts of General Jurisdiction to Internet Contacts, 52 LOY. L. REV. 147, 148 (2006) (arguing that analysis focusing exclusively on quantitative sales territory may subject defendants to jurisdiction in unforeseen forums); Kristin Woeste, Comment, General Jurisdiction and the Internet: Sliding Too Far?, 73 U. CIN. L. REv. 793, 793-94 (2004) ("There is no [judicial] consensus [for] how to [evaluate] web-based contacts for [purposes of] general jurisdiction ....”). Members of the Court have expressed concern with the application of jurisdictional rules to Internet activity. See, e.g., J. McIntyre Mach., Ltd. v. Nicastro, 131 S. Ct. 2780, 2793 (2011) (Breyer, J., concurring) (raising questions about the application of strict rules proposed by the plurality to common Internet transactions).

302. U.S. CONST. amend. XIV. The Commerce Clause might provide a separate ground for limiting state court jurisdiction over unrelated out-of-state sales. See U.S. Const. art. 1, § 8, cl. 3.

303. Justice Ginsburg's opinion does not resolve the issue that has divided lower courts. See supra notes 161-64 and accompanying text; cf. Gator.Com Corp. v. L.L. Bean, Inc., 341 F.3d 1072, 1074 (9th Cir. 2003) (subjecting an Internet vendor to general jurisdiction based on the volume of sales in California, despite the fact that most of the sales were in other states), dismissed as moot by 398 F.3d 1125 (9th Cir. 2005) (en banc).

304. Goodyear Dunlop Tires, 131 S. Ct. at 2855. 
practical problem that the Court has never directly addressed. The Court's analysis strongly suggests that while a state may properly subject a defendant to specific jurisdiction for claims relating to its activity in the state, it may not simultaneously subject the defendant to general jurisdiction for claims unrelated to its activity in the forum. This is arguably the wrong result as a matter of policy and tradition.

\section{Hard Cases After Goodyear Dunlop Tires}

1. Presence Based on Offices, Facilities, or Centralized Activities in State

Goodyear Dunlop Tires does not answer the question of whether a nonresident corporation is "at home" and subject to general jurisdiction in a state where it does not do most of its business but where it maintains an office or other facilities or where it regularly employs agents who conduct in-state business. ${ }^{305}$ The decision also does not answer whether a corporation is subject to general jurisdiction when it maintains a transient but recurring presence in the forum state and also coordinates sales or other commercial activity from that state that covers a multi-state region. For example, the opinion does not indicate whether a foreign manufacturer is subject to general jurisdiction in a state where it repeatedly meets with buyers and promotes products that are delivered in other states. $^{306}$

\section{Enterprise Theory}

Leaving until tomorrow the type of circumstance that support attributing one corporation's activity or contacts to another under an enterprise theory, ${ }^{307}$ the Court invites future litigation without providing

\footnotetext{
305. The opinion provides no answer to the question raised during argument as to whether North Carolina could subject Goodyear USA to general jurisdiction based on the fact that Goodyear operates a manufacturing facility and engages in commercial activity in the state. See supra notes 17 and 289 and accompanying text.

306. The president of the foreign manufacturer in Nicastro attended a trade show in Nevada that may have resulted in the manufacturer's importing products into New Jersey. Nicastro, $131 \mathrm{~S}$. Ct. at 2796 (Ginsburg, J., dissenting). General jurisdiction would not be proper in Nevada because trade shows were held throughout the country. A harder case would arise if Nevada hosted an annual trade fair that served as the commercial center through which the foreign corporation coordinated sales.

307. See supra notes $176-78$ and accompanying text.
} 
insight as to the legal source of the as yet-unarticulated rules to govern such attribution. May a forum state apply its own law governing the piercing of a corporate veil? Must it apply the law of the corporation's other "home" states? Does the Due Process Clause provide a separate source of rules regarding such enterprise-based jurisdiction? Stay tuned.

\section{E. Prospects for State Legislation}

States have the power to avoid constitutional uncertainties and to provide greater clarity by restricting the scope of long-arm personal jurisdiction. For example, state legislation could remove much of the uncertainty created by Goodyear Dunlop Tires by removing general jurisdiction based on service on a corporate agent within the state and restricting general jurisdiction to corporations that incorporate in or maintain their principal places of business in the state. State legislation could further avoid constitutional problems by defining principal place of business so narrowly that it would satisfy any constitutional demandsperhaps by defining such a place as the corporate headquarters where management level decision-making takes place. Nevertheless, legislatures have generally refrained from shrinking personal jurisdiction for the purpose of avoiding constitutional controversies. Indeed, the controversies have arisen, as in Goodyear Dunlop Tires, precisely because state legislatures and courts have attempted to expand personal jurisdiction beyond clearly demarcated traditional categories.

Although state legislatures cannot authorize state courts to exercise jurisdiction where doing so violates the Due Process Clause, states may effectively provide local forums for their residents by enacting new remedies that expand the range of responsible parties to include more defendants that can be subjected to their courts' general jurisdiction. For example, legislatures could respond to the restriction of specific jurisdiction over nonresident tortfeasors by enacting direct-action statutes that authorize proceedings directly against tortfeasors' insurance companies. The insurance companies may be subject to general jurisdiction even if the tortfeasors are not.

Direct actions were once on law reformers agendas in several states. ${ }^{308}$ The Court alleviated the need for direct actions by recognizing

308. See generally Jonathan C. Augustine, Other States Should "Get with the Program" and Follow Louisiana's Lead: An Examination of Louisiana's Direct Action Statute and Its Application in the Marine Insurance Industry, 27 TUL. MAR. L.J. 109, 113-17 (2002) (discussing the history of the Louisiana direct action statutes); Alston Johnson, The Louisiana Direct Action Statute, 43 LA. L. 
the expanding power of states over nonresident tortfeasors. ${ }^{309}$ The restriction of personal jurisdiction announced in Goodyear Dunlop Tires and Nicastro provides new incentives for enacting such remedies. The broadest possible statutes would impose direct liability on any person who has a duty to indemnify the foreign corporation for claims arising out of injuries in the state. Such a statute would authorize direct action against a foreign manufacturer's insurance company in any state where the insurer is subject to general jurisdiction and would similarly authorize such actions in the home state of any corporation that has a duty to indemnify the tortfeasor. ${ }^{310}$

\section{F. Prospects for Federal Legislation}

Scholars have generally assumed that, like the states, Congress may impose further restrictions on personal jurisdiction but is powerless to expand personal jurisdiction beyond the limits recognized by the Court. ${ }^{311}$ Unlike states, however, federal courts have never been authorized to exercise the broadest possible personal jurisdiction. For most cases, personal jurisdiction of a federal court is the same as that of the courts of the state in which it sits. ${ }^{312}$

Although a state court might lack personal jurisdiction based on the absence of sufficient contacts within the state, a federal court sitting in the same state could constitutionally exercise personal jurisdiction if there were sufficient contacts with the United States as a whole. ${ }^{313}$ For

REV. 1455, 1455-66 (1983) (discussing the history of direct action statutes).

309. See Parts III.B.1-2.

310. Imposing a greater legal obligation on insurers than they assumed by contract does not violate due process. Watson v. Emp'rs Liab. Assurance Corp., 348 U.S. 66, $73-74$ (1954) (holding that Louisiana's interest in protecting persons injured in the state permitted recovery under direct action against a nonresident insurer, notwithstanding a provision in the insurance agreement that prohibited such claims until after recovery of a judgment against the tortfeasor).

311. Juenger discusses prospects for federal legislation in the context of proposals for federalizing the law for recognizing judgments. See Juenger, supra note 238, at 166-67. He assumes that "the Supreme Court's insistence on the constitutional nature of jurisdictional law" would present an obstacle to any federal law purporting to expand personal jurisdiction. Id. at 167. Juenger also assumes that political or constitutional considerations would impede federal legislation limiting state court jurisdiction. Id. at 166-67. Borchers similarly assumes that the constitutional ground of the Supreme Court's decisions preclude federal legislation or treaties expanding personal jurisdiction. Borchers, supra note 18, at 133-34. He suggests that state long-arm statutes or federal legislation could provide clarity only by imposing restrictions on jurisdiction. Id. at 133 .

312. See FED. R. CIV. P. 4(k)(1)(A) (authorizing personal jurisdiction over a defendant "who is subject to the jurisdiction of a court of general jurisdiction in the state where the district court is located”).

313. The issue was raised by Justice O’Connor in Asahi. 480 U.S. 102, 113 n.* (1987) (plurality 
example, where a foreign defendant's product causes injury in the state but the foreign defendant does not have minimum contacts with the state, due process would prevent state courts from exercising personal jurisdiction. In contrast, due process would not prevent federal courts in the state from exercising personal jurisdiction so long as the foreign defendant had minimum contacts with other states or with the United States as a whole.

The problem, however, is that federal courts are not currently authorized to exercise such broad jurisdiction. Though the political prospects for enlarging federal jurisdiction appear poor at the moment, ${ }^{314}$ Justice Kennedy's plurality opinion in Nicastro invited federal legislation to address this jurisdictional gap. ${ }^{315}$

Congress could remedy this situation by crafting a new federal cause of action for injuries suffered in the United States as a result of activity that occurs outside the United States. ${ }^{316}$ The new cause of action would

opinion) ("We have no occasion here to determine whether Congress could, consistent with the Due Process Clause of the Fifth Amendment, authorize federal court personal jurisdiction over alien defendants based on the aggregate of national contacts....”). No bill has apparently yet been introduced authorizing such jurisdiction. Cf. The Foreign Manufacturers Legal Accountability Act of 2009, S. 1606, 111th Cong. §§ 3, 5 (2009) (requiring "foreign manufacturers of products imported into the United States” to appoint agents, which constitutes consent, but not providing for personal jurisdiction over defendants that do not appoint agents). The Chamber of Commerce of the United States of America argued that permitting North Carolina to exercise personal jurisdiction would "[d]amage [e]fforts by the United States to [c]omplete a [t]reaty on [j]urisdiction and [j]udgments." Brief of the Chamber of Commerce of the United States of America as Amicus Curiae in Support of Petitioners at 18-21, Goodyear Dunlop Tires Operations, S.A. v. Brown, 131 S. Ct. 2846 (2011) (No. 10-76).

314. Viewing restraint of jurisdiction as conducive to economic development and trade, the Obama administration filed a brief in support of the position of the defendants in Goodyear Dunlop Tires. See Brief for the United States as Amicus Curiae Supporting Petitioners, Goodyear Dunlop Tires, 131 S. Ct. 2846 (No. 10-76).

315. See J. McIntyre Mach., Ltd. v. Nicastro, 131 S. Ct. 2780, 2789 (2011) (plurality opinion) (" $[\mathrm{A}]$ defendant may in principle be subject to the jurisdiction of the courts of the United States but not of any particular State.”).

316. It would be possible but unnecessary to state that such causes of action would require the defendant to have minimum contacts with the United States. The Due Process Clause would independently operate to prevent jurisdiction in the absence of such contacts. See U.S. Const. amend. XIV, § 1. Congressional authority to enact the new claim would derive from the power to regulate interstate and international commerce under the Commerce Clause. U.S. ConsT. art. I, § 8, cl. 3. Federal courts have subject matter jurisdiction over such claims. 28 U.S.C. § 1331 (2006) (giving district courts "original jurisdiction of all civil actions arising under the Constitution, laws, or treaties of the United States"). To avoid unnecessary litigation over the outer reaches of the Commerce Clause, it would probably be desirable to list specific kinds of activity that fall within the cause of action. For example, the statute might apply to items manufactured for sale outside the country in which they were manufactured.

Alternatively, Congress could enact a statute that authorizes nationwide service of process over corporations that engage in such substantial activity in the United States that the federal courts may 
potentially place a greater burden on federal judicial systems, channeling into federal court cases arising under state law that were historically within the exclusive subject matter jurisdiction of state courts. ${ }^{317}$ But by restricting the cause of action to cases over which no state court has personal jurisdiction, Congress would avoid interfering with existing state judicial authority.

It is doubtful whether less aggressive methods could effectively close the jurisdictional gap. For example, federal legislation that creates a new cause of action but requires its litigation in state court $^{318}$ or federal legislation that attempts to authorize state court personal jurisdiction based on a defendant's contacts with the United States as a whole would both fail to avoid the objection that Congress lacks authority to expand the personal jurisdiction of the state courts beyond what due process permits. ${ }^{319}$

Justice Ginsburg's opinion in Goodyear Dunlop Tires suggests the existence of a second jurisdictional gap. In some cases, foreign corporations based outside the United States could have continuous and systematic contacts with the United States as a whole so that federal courts could constitutionally exercise general jurisdiction, yet the corporations might simultaneously lack sufficient contacts to permit

constitutionally exercise personal jurisdiction over such corporations. This would extend to diversity cases the procedure that currently authorizes personal jurisdiction over defendants in federal question claims when the defendants are not subject to personal jurisdiction in any state. See FED. R. CIV. P. 4(k)(2)(A) (authorizing personal jurisdiction for claims based on federal law over a defendant when "the defendant is not subject to jurisdiction in any state's courts of general jurisdiction”). Indeed, Congress could achieve this result by eliminating Rule 4(k)(2)'s first eight words-“[f]or a claim that arises under federal law." See FED. R. CIV. P. 4(k)(2). This change could not be effected so readily by a mere change in the rules. See 28 U.S.C. § 2072(a)-(b) (limiting rulemaking to rules of practice and procedure that do not enlarge substantive rights); FED. R. CIV. P. 82 (stating that federal rules do not extend jurisdiction of federal courts).

Enlarging personal jurisdiction over claims currently within the subject matter jurisdiction of the federal courts would provide an incomplete solution to the jurisdictional gap. It would still not provide a forum for cases that fail to meet the technical requirements for federal diversity of citizenship.

317. The statute would authorize federal jurisdiction over a large number of cases based on nonfederal law that were not previously within federal court subject matter jurisdiction based on diversity of citizenship or some other ground of federal jurisdiction.

318. There is ample authority for giving state courts exclusive original jurisdiction over federal claims. Indeed, the first Judiciary Act did not give such jurisdiction to federal trial courts. See Judiciary Act of 1789, ch. 20, 1 Stat. 73 (1789). Moreover, Congress has previously enacted legislation to address a loophole in state law but at the same time required litigation in state courts. See Parental Kidnapping Prevention Act (PKPA), 28 U.S.C. §1738A (2006); Thompson v. Thompson, 484 U.S. 174, 182-83, 187 (1988) (holding that PKPA requires states to enforce custody determinations from other states but does not create a federal cause of action).

319. See supra note 311. 
general jurisdiction in any individual state court. An example would be an English corporation headquartered in London, the sole business of which consists of selling toxic American flag candy throughout the United States that is purchased from vendors in East Asia. If the corporation spreads its sales evenly throughout the United States, then no state would qualify as the corporation's principal place of business. Thus, the corporation would fail to have sufficient continuous and systematic contacts in any single state to support general jurisdiction.

A federal statute authorizing personal jurisdiction over foreign defendants that cause injuries in states would fill the jurisdictional gap for most cases. But such a statute authorizes a form of specific jurisdiction that would still leave U.S. citizens deprived of a domestic forum when their claim arose outside the United States. This would be the case if a child who is a citizen of the United States ingested the toxic candy in Canada. Congress could close this gap by authorizing federal courts to exercise general jurisdiction over foreign corporations engaged in continuous and systematic business in the United States, but it is questionable whether Congress will have the political will to do so in the immediate future.

\section{CONCLUSION}

The consensus of the Supreme Court in Goodyear Dunlop Tires conceals important areas of divergence with immediate practical consequences. On the one hand, the opinion can be read narrowly as affirming the exclusive classification of cases into specific and general jurisdiction and disallowing general jurisdiction over foreign manufacturers based solely on sporadic sales through intermediaries. On the other hand, it can be read broadly as effectively ending general jurisdiction over nonresident corporations by restricting general jurisdiction to corporations that incorporate under the laws of the state, maintain their principal place of business in the state, or have such a comparably close connection with the state so that they are "at home" in the state.

Rejecting general jurisdiction under the facts of the case, Justice Ginsburg's opinion conflates a variety of approaches but fails to communicate a coherent, shared vision of the underlying principles of personal jurisdiction. ${ }^{320}$ Avoiding divisive details such as the need for

320. Twitchell observed that lack of policy analysis indicated that "courts are unsure about what 
physical presence in the state, the broad opinion comports equally with two incongruous agendas. It comports with liberal reform-oriented proposals to rationalize personal jurisdiction by eliminating most forms of general jurisdiction while expanding specific jurisdiction. ${ }^{321}$ And it comports with libertarian proposals to curtail both general jurisdiction and specific jurisdiction. ${ }^{322}$

This Article argues that even the most generous reading of the opinion leaves important practical questions unanswered. Does service on an agent confer valid general jurisdiction? Will contacts-based general jurisprudence apply to individuals as well as corporations? Can significant and continuous contacts support general jurisdiction in multiple states or are they the functional equivalent of the principal place of business? Can a corporation maintain more than one principal place of business? Is the principal place of business defined by the nervecenter or some other test?

The Court's curtailment of specific jurisdiction in Nicastro will impel plaintiffs seeking a local forum to invoke general jurisdiction in ever more cases. This will require lower courts to address the host of issues evaded by the broad and ambiguous opinion in Goodyear Dunlop Tires that was capable of commanding consensus.

policies support this exercise of [general] jurisdiction.” Twitchell, supra note 103, at 637. Perhaps, after Goodyear Dunlop Tires, the observation should be amended: lack of policy analysis may indicate that individual justices are sure about what policies support jurisdiction. They just cannot agree about what the policies are.

321. See supra note 248-50 and accompanying text (citing von Mehren and Trautman, supra note 3, 1164-65, 1167-68, 1172, 1177). But see Borchers, supra note 18, at 139 ("General jurisdiction's defects cannot be separated from those of specific jurisdiction.”).

322. See supra note 256 (citing J. McIntyre Mach. Ltd. v. Nicastro, 131 S. Ct. 2780, 2787 (2011) (plurality opinion)). 